\title{
Laser-induced fluorescence-based detection of atmospheric nitrogen dioxide and comparison of different techniques during the PARADE 2011 field campaign
}

\author{
Umar Javed $^{1,2}$, Dagmar Kubistin ${ }^{1,3,4}$, Monica Martinez ${ }^{1}$, Jan Pollmann $^{1}$, Markus Rudolf ${ }^{1}$, Uwe Parchatka $^{1}$, \\ Andreas Reiffs ${ }^{1}$, Jim Thieser ${ }^{1}$, Gerhard Schuster ${ }^{1}$, Martin Horbanski ${ }^{5}$, Denis Pöhler ${ }^{5}$, John N. Crowley ${ }^{1}$, \\ Horst Fischer $^{1}$, Jos Lelieveld ${ }^{1}$, and Hartwig Harder ${ }^{1}$ \\ ${ }^{1}$ Department of Atmospheric Chemistry, Max Planck Institute for Chemistry, Mainz, Germany \\ ${ }^{2}$ Institute of Energy and Climate Research, IEK-8: Troposphere, Forschungszentrum Jülich GmbH, Jülich, Germany \\ ${ }^{3}$ University of Wollongong, School of Chemistry, Wollongong, NSW, Australia \\ ${ }^{4}$ German Meteorological Service, Meteorological Observatory Hohenpeissenberg (MOHp), Hohenpeissenberg, Germany \\ ${ }^{5}$ Institute of Environmental Physics, University of Heidelberg, Heidelberg, Germany
}

Correspondence: Hartwig Harder (hartwig.harder@mpic.de) and Umar Javed (u.javed@fz-juelich.de)

Received: 27 June 2018 - Discussion started: 5 July 2018

Revised: 17 December 2018 - Accepted: 28 December 2018 - Published: 7 March 2019

\begin{abstract}
GANDALF (Gas Analyzer for Nitrogen Dioxide Applying Laser-induced Fluorescence), a new instrument for the detection of nitrogen dioxide based on the laserinduced fluorescence (LIF) technique, is presented in this paper. GANDALF is designed for ground-based and airborne deployment with a robust calibration system. In the current set-up, it uses a multi-mode diode laser (447-450 nm) and performs in situ, continuous, and autonomous measurements with a laser pulse repetition rate of $5 \mathrm{MHz}$. The performance of GANDALF was tested during the summer of year 2011 (15 August-10 September) in a field experiment at Kleiner Feldberg, Germany. The location is within a forested region with an urban influence, where $\mathrm{NO}_{x}$ levels were between 0.12 and 22 parts per billion by volume (ppb). Based on the field results, the limit of detection is estimated at 510 parts per trillion by volume (ppt) in $60 \mathrm{~s}$ at a signal-tonoise ratio (SNR) of 2 . The overall accuracy and precision of the instrument are better than $5 \%(1 \sigma)$ and $0.5 \%+3 \mathrm{ppt}$ $\left(1 \sigma \min ^{-1}\right)$, respectively. A comparison of nitrogen dioxide measurements based on several techniques during the field campaign PARADE 2011 is presented to explore methodic differences.
\end{abstract}

\section{Introduction}

Tropospheric nitric oxide (NO) and nitrogen dioxide $\left(\mathrm{NO}_{2}\right)$ are key species in atmospheric chemistry and are strongly coupled due to their fast photochemical interconversion generally combined as $\mathrm{NO}_{x}\left(=\mathrm{NO}+\mathrm{NO}_{2}\right)$. Nitrogen oxides act as a key catalyst in the formation of tropospheric ozone $\left(\mathrm{O}_{3}\right)$ (Crutzen, 1979). $\mathrm{NO}_{x}$ also plays an important role in the oxidation capacity of the troposphere by affecting the abundances of $\mathrm{O}_{3}$, hydroxyl radical $(\mathrm{OH})$, and nitrate radical $\left(\mathrm{NO}_{3}\right)$.

The main sources of $\mathrm{NO}_{x}$ in the troposphere are combustion processes, predominantly fossil fuel use, biomass burning, microbial production in soils, transport from the stratosphere and lightning, the latter two directly affecting the free troposphere (e.g. Logan, 1983), along with aircraft emissions (Strand and Hov, 1996). $\mathrm{NO}_{x}$ emissions from the surface are mostly in the form of $\mathrm{NO}$, which is converted to $\mathrm{NO}_{2}$ by the reaction of $\mathrm{NO}$ with $\mathrm{O}_{3}$, the hydroperoxyl radical $\left(\mathrm{HO}_{2}\right)$, organic peroxy radicals $\left(\mathrm{RO}_{2}\right)$, and halogen oxides. The oxidation of nitrogen oxides in the atmosphere leads to the formation of several reactive nitrogen species, some of which act as reservoirs for $\mathrm{NO}_{x}$, denoted by $\mathrm{NO}_{z}{ }^{1}$. The $\mathrm{NO}_{x}$ lifetime

\footnotetext{
${ }^{1} \mathrm{NO}_{z}=\mathrm{NO}_{3}+2 \mathrm{~N}_{2} \mathrm{O}_{5}+\mathrm{HNO}_{3}+\mathrm{HONO}+\mathrm{RO}_{2} \mathrm{NO}_{2}+$ $\mathrm{RONO}_{2}+\mathrm{HNO}_{4}+$ Particulate Nitrate $+\ldots$
} 
is largely determined by its oxidation into nitric acid $\left(\mathrm{HNO}_{3}\right)$ by $\mathrm{OH}$ during the daytime, and also in polluted air through the heterogeneous loss of $\mathrm{N}_{2} \mathrm{O}_{5}$ (formed by $\mathrm{NO}_{2}+\mathrm{NO}_{3}$ ) on wet surfaces at night, e.g. on aerosols and cloud droplets. The tropospheric lifetime of $\mathrm{NO}_{x}$ is in the range of hours to days and it is generally shorter closer to the surface of Earth compared to high altitudes (e.g. Ehhalt et al., 1992). Because of its relatively short lifetime, the transport distance of $\mathrm{NO}_{x}$ is limited compared to other primary pollutants like carbon monoxide $(\mathrm{CO})$ and methane $\left(\mathrm{CH}_{4}\right)$ that disperse on hemispheric and global scales.

The wet and dry deposition of $\mathrm{HNO}_{3}$ is considered the major sink for $\mathrm{NO}_{x}$. Uncertainties in the $\mathrm{NO}_{x}$ budget have recently been highlighted (Stavrakou et al., 2013). These include the uncertainty in the estimate of the rate coefficient for $\mathrm{NO}_{2}+\mathrm{OH}$ under tropospheric conditions (Mollner et al., 2010), a lack of proper representation in chemical mechanisms for the loss of $\mathrm{NO}_{x}$ via organic nitrate formation (Browne and Cohen, 2012), and the formation of $\mathrm{HNO}_{3}$ in a minor branch of the reaction between $\mathrm{NO}$ and $\mathrm{HO}_{2}$ (Butkovskaya et al., 2007), which showed significant impacts on the concentrations of $\mathrm{NO}_{x}, \mathrm{OH}, \mathrm{HNO}_{3}$, and related chemistry (Cariolle et al., 2008; Gottschaldt et al., 2013). Additionally, a lack of agreement between modelled and measured $\mathrm{OH}$ concentrations over forests (Lelieveld et al., 2008; Kubistin et al., 2010) and urban regions (Hofzumahaus et al., 2009) contribute to the uncertainty in $\mathrm{NO}_{x}$ chemistry. In summary, $\mathrm{NO}_{x}$, even in the low ppt range is important for understanding the tropospheric $\mathrm{O}_{3}$ production (Lelieveld and Crutzen, 1990; Carpenter et al., 1997) and the cycling of radicals (Monks, 2005). Therefore, it is of great importance to have accurate $\mathrm{NO}_{x}$ measurements from regional to global scales.

Tropospheric mixing ratios of $\mathrm{NO}_{x}$ can vary from a few ppt to hundreds of $\mathrm{ppb}$, depending on remote (Hosaynali Beygi et al., 2011) and urban conditions (Clapp and Jenkin, 2001). The high temporal and spatial variability of $\mathrm{NO}_{x}$ with the wide concentration ranges challenges its measurements. Briefly, several different methods have been used to measure $\mathrm{NO}_{x}$ in the atmosphere. The photofragmentation two-photon laser-induced fluorescence (PF-TP-LIF) (Sandholm et al., 1990; Bradshaw et al., 1999) and chemiluminescence (Fontijn et al., 1970) methods are well known for direct in situ NO detection. In the past, an indirect detection of $\mathrm{NO}_{2}$ with these techniques has been performed by converting $\mathrm{NO}_{2} \rightarrow \mathrm{NO}$ via photolytic/catalytic process followed by $\mathrm{NO}$ detection. However, in the case of $\mathrm{NO}_{2}$ to $\mathrm{NO}$ conversion, a potential interference from $\mathrm{NO}_{z}$ species cannot be fully excluded for the $\mathrm{NO}_{2}$ measurement, (e.g. Crawford et al., 1996; Villena et al., 2012; Reed et al., 2016). Therefore, a direct detection of $\mathrm{NO}_{2}$ is advantageous. Techniques like cavity ring-down absorption spectroscopy (Osthoff et al., 2006), tunable diode laser absorption spectroscopy (Herndon et al., 2004), cavity-enhanced absorption spectroscopy (Wojtas et al., 2007), cavity-enhanced differential optical ab- sorption spectroscopy (Platt et al., 2009), and cavity attenuated phase shift spectroscopy (Ge et al., 2013) provide direct in situ detection of $\mathrm{NO}_{2}$. Another promising method for direct $\mathrm{NO}_{2}$ detection is based on the laser-induced fluorescence technique. The LIF method for $\mathrm{NO}_{2}$ provides highly selective and sensitive measurements and it has already been demonstrated successfully in the past with detection limits reaching down to about 5 ppt $\min ^{-1}$ (Thornton et al., 2000; Matsumoto and Kajii, 2003).

An overview of LIF $\mathrm{NO}_{2}$ systems from the literature is given in Table 1. LIF systems have been used for many years but the detection limits are sometimes not suitable for detection in a remote region, especially in some of the earlier attempts (George and Obrien, 1991; Fong and Brune, 1997; Matsumoto et al., 2001; Taketani et al., 2007). In the last decade, owing to the advancements in lasers, better detection limits have been achieved. The LIF systems have shown good selectivity and sensitivity (Thornton et al., 2000; Matsumi et al., 2001; Matsumoto and Kajii, 2003; Dari-Salisburgo et al., 2009; Di Carlo et al., 2013), but most of these systems have large (typically $>50 \mathrm{~kg}$ ) and complex laser systems. The availability of much smaller and lighter diode lasers have made it possible to build compact instruments with the caveat of lower laser power and higher detection limits. Here, for GANDALF, a high power, lightweight diode laser $(<2 \mathrm{~kg})$ system is used to achieve a compact design with detection limits comparable to those of the best-performing larger instruments.

In the following, the newly developed LIF instrument is described for the direct $\mathrm{NO}_{2}$ detection. Results from the first field deployment in a semi-rural region are reported to demonstrate the performance of the instrument. Measurements of trace gases along with meteorological parameters were carried out during the campaign, including $\mathrm{NO}_{2}$ measurements based on several techniques, namely LIF, cavity ring-down absorption spectroscopy, two-channel chemiluminescence detection, cavity-enhanced differential optical absorption spectroscopy, and long-path differential optical absorption spectroscopy. Being the first deployment of GANDALF, this opportunity provided the means for a detailed comparison to other methods under real atmospheric conditions.

\section{The instrument description}

\subsection{The operational method}

The measurements of GANDALF are based on laser-induced fluorescence at low pressure $(<10 \mathrm{hPa})$. The $\mathrm{NO}_{2}$ molecule is excited by a diode laser with a wavelength well above the photolysis threshold $\left(\lambda>420 \mathrm{~nm}\right.$ for $\left.\mathrm{NO}_{2}\right)$ and the redshifted fluorescence is detected during laser-off periods.

$$
\begin{gathered}
\mathrm{NO}_{2}+h v(\lambda=449 \mathrm{~nm}) \rightarrow \mathrm{NO}_{2}^{*} \\
\mathrm{NO}_{2}^{*} \rightarrow \mathrm{NO}_{2}+h v^{\prime}(\lambda \geq 449 \mathrm{~nm})
\end{gathered}
$$


Table 1. Overview of different LIF instruments.

\begin{tabular}{llllll}
\hline Reference & $\begin{array}{l}\lambda^{\text {laser type }} \\
(\mathrm{nm})\end{array}$ & $\begin{array}{l}\text { Laser power } \\
(\mathrm{mW})\end{array}$ & $\begin{array}{l}\text { Absorption cross section } \\
\left(\times 10^{-19}\right) \mathrm{cm}^{2} \text { molecules }^{-1}\end{array}$ & $\begin{array}{l}\text { Cell pressure } \\
(\mathrm{Pa})\end{array}$ & $\begin{array}{l}\text { LOD } \\
\left(\mathrm{ppt} \mathrm{min}^{-1}\right)\end{array}$ \\
\hline George and Obrien (1991) & $532^{\mathrm{a}}$ & 250 & 1.5 & 37 & 600 \\
Fong and Brune (1997) & $565^{\mathrm{b}}$ & 250 & 0.6 & 1000 & 460 \\
Thornton et al. (2000) & $585^{\mathrm{c}}$ & $100-400$ & 1 & 467 & 6 \\
Matsumi et al. (2001) & $440^{\mathrm{d}}$ & 100 & 7 & 35 & 12 \\
Matsumoto et al. (2001) & $523.5^{\mathrm{e}}$ & 360 & 1.4 & 93 & 125 \\
Cleary et al. (2002) & $640.2^{\mathrm{f}}$ & 16 & $3.9(\mathrm{C})$ & 27 & 145 \\
Matsumoto and Kajii (2003) & $532^{\mathrm{g}}$ & 6500 & 1.5 & 267 & 4 \\
Taketani et al. (2007) & $410^{\mathrm{h}}, 473^{\mathrm{i}}$ & 10,15 & 6,3 & 67 & 390,140 \\
Parra and George (2009) & $406.3^{\mathrm{j}}$ & 35 & 6 & 60 & Ambient \\
Dari-Salisburgo et al. (2009) & $532^{\mathrm{k}}$ & $8000-12000$ & 1.5 & 533 & $2000(\mathrm{~A})$ \\
Di Carlo et al. (2013) & $532^{1}$ & 38000 & 1.5 & 700 & $9.8(\mathrm{~s}-1)$ \\
GANDALF & $447-450^{\mathrm{m}}$ & Max 200 & $5.3(\mathrm{E})$ & $5-10$ \\
\hline
\end{tabular}

(E) Effective absorption cross section. (C) Cooling enhancement. (A) Ambient pressure in the detection cell.

Laser type (column 2):

${ }^{a}$ Nd: YAG laser. ${ }^{b}$ Copper vapour laser-pumped dye laser. ${ }^{c}$ Pulsed YAG-pumped dye laser. ${ }^{d}$ Optical parametric oscillator laser. ${ }^{\mathrm{e}}$ Nd:YLF laser harmonic.

${ }^{\mathrm{f}}$ External-cavity tunable diode laser. ${ }^{\mathrm{g}} \mathrm{Nd}: \mathrm{YVO}_{4}$ pulse laser pumped by a solid-state laser. ${ }^{\mathrm{h}} \mathrm{GaN}$-based laser diode. ${ }^{\mathrm{i}}$ Diode-pumped Nd:YAG laser. ${ }^{\mathrm{j}} \mathrm{CW}$ GaN semiconductor laser diode. ${ }^{\mathrm{k}}$ YAG Q-switched intra-cavity doubled laser. ${ }^{1}$ YAG Laser (Nd:YVO4 pulse laser). ${ }^{\mathrm{m}} \mathrm{CW}$ diode laser.

The $\mathrm{NO}_{2}$ fluorescence has a broad spectrum. It starts at the excitation wavelength and extends into the infrared region (Wehry, 1976). However, the major fraction of the fluorescence still lies in the visible region (Sakurai and Broida, 1969; Sugimoto et al., 1982). The detected fluorescence $h v^{\prime}$ is directly proportional to the amount of $\mathrm{NO}_{2}$ in the cell. The background signal due to scattering and dark counts of the detector is determined by frequently measuring zero air (zero $\mathrm{NO}_{2}$ ). The atmospheric mixing ratios of $\mathrm{NO}_{2}$ are derived by using Eq. (1).

$\mathrm{NO}_{2}=\left[\frac{\text { signal }-S_{\mathrm{BG}}}{\alpha_{\mathrm{c}}}\right]$

where "signal" is in counts $\mathrm{s}^{-1}$ and $\alpha_{\mathrm{c}}$ is the calibration factor or sensitivity in counts $\mathrm{s}^{-1} \mathrm{ppb}^{-1} . \alpha_{\mathrm{c}}$ is derived from the slope of counts vs. known amounts of $\mathrm{NO}_{2} . S_{\mathrm{BG}}$ is the background signal in counts $\mathrm{s}^{-1}$. The quality of zero air is further discussed in Sect. 3.

The mechanical and optical parts of the LIF detection axis are presented schematically in Fig. 1. All mechanical parts inside GANDALF are black anodized and most optical components are continuously flush with zero air/nitrogen $(3 \times 50 \mathrm{sccm})$ (Fig. 1, no. 1) during the period of operation to avoid dead air pockets, fog, dust, etc. The inlet for the sampling flow line is a small orifice with a diameter of $0.7 \mathrm{~mm}$. The distance from the point of entrance at the orifice to the centre of the detection cell (Fig. 1, no. 2) is about $150 \mathrm{~mm}$. This combination of orifice size and scroll pump provides a pressure of $7 \mathrm{hPa}$ inside the detection cell, with a sampling flow of about $4100 \mathrm{sccm}$. The time required for air molecules from the point of entrance to reach the centre of the detection

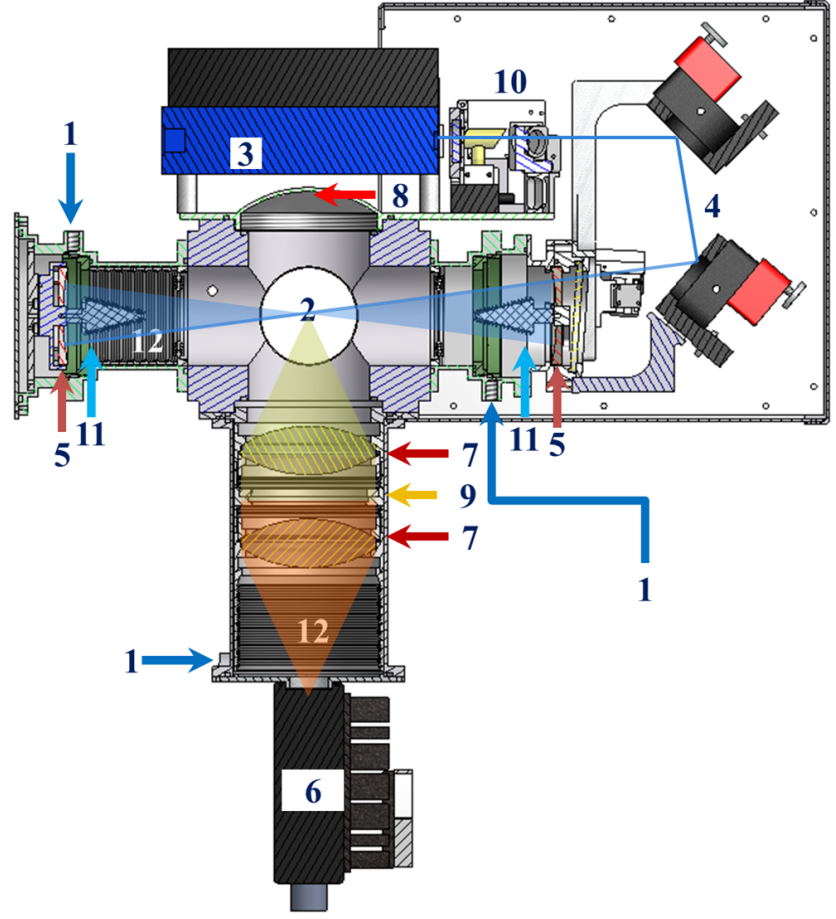

Figure 1. Section view of GANDALF (section view is based on Inventor 2009. The figure is created by defining a plane used to cut through the whole assembly. 3-D AutoCAD models (1) for the diode laser by courtesy of Omicron Laserage Laserprodukte $\mathrm{GmbH}$ and (2) for optical mirror holders by courtesy of Newport). (1) Flushing for optics. (2) Detection area. (3) Diode laser. (4) Motorized mirrors; (5) Herriott cell's mirrors. (6) PMT. (7) Focusing lens. (8) Concave mirror. (9) Interference/optical filters. (10) Optical reference system. (11) and (12) Baffles. 
cell is less than $30 \mathrm{~ms}$. The diode laser ${ }^{2}$ (Fig. 1, no. 3) in this system has a maximum output power of $250 \mathrm{~mW}$ with an onoff modulation frequency of $5 \mathrm{MHz}$. The wavelength $(\lambda)$ of the diode laser is in the range of $447 \rightarrow 450 \mathrm{~nm}$. The convolution of the laser profile and the $\mathrm{NO}_{2}$ absorption cross section (Vandaele et al., 2002) yields an effective $\mathrm{NO}_{2}$ absorption cross section of $5.3 \times 10^{-19} \mathrm{~cm}^{2}$ molecule ${ }^{-1}$. The laser beam is directed into the detection cell by using motorized mirrors (Fig. 1, no. 4). These mirrors are coated to achieve high reflectivity $(99.8 \%)$ for a light incidence at $45^{\circ}$ with a wavelength of $450 \mathrm{~nm}$. A Herriot cell (Herriott et al., 1964) is used to produce multiple passes to enhance the laser light and focus at the centre of the detection cell. The detection cell of GANDALF is positioned between the Herriott cell mirrors (Fig. 1, no. 5), which have approximately $99.99 \%$ reflectivity (IBS coating; ATFilms (IBS coating), USA) in the spectral range of 445 to $455 \mathrm{~nm}$. The distance between the mirrors is twice their radius of curvature $(R=128 \mathrm{~mm})$. Any fluorescent contaminants from the mirrors are measured as a part of the background signal. The multi-passed laser beam encompass a circle of about $8-10 \mathrm{~mm}$ diameter at the centre of the detection cell. A photomultiplier tube ${ }^{3}$ (PMT) is used for the fluorescence detection. The PMT is located in a tube (Fig. 1, no. 6) perpendicular to the sampling flow line. The effective sensor area of the PMT is $5 \mathrm{~mm}$ in diameter and has a GaAsP/GaAs photocathode (Radiant sensitivity of $87.4 \mathrm{~mA} \mathrm{~W}^{-1}$ ). The PMT is sensitive to wavelengths between $380 \mathrm{~nm}$ and $890 \mathrm{~nm}$, with peak sensitivity at $800 \mathrm{~nm}$ with a maximum quantum efficiency of $12 \%$. The fluorescence signal is focused onto the PMT by collimating lenses (Fig. 1, no. 7). An aluminium concave mirror (Fig. 1, no. 8) located opposite the PMT redirects additional fluorescence photons towards the detector. In front of the PMT, interference filters (Barr Associates, Inc., USA) (Fig. 1, no. 9) are used to remove contributions of light scattered from the walls of the sampling chamber, as well as from Rayleigh and Raman scattering. The filters have the cut-off wavelengths (block radiation below this wavelength) of 470 and $550 \mathrm{~nm}$, with an average transmission of $98 \%$ in the spectral range from cut-off wavelength +3 to $900 \mathrm{~nm}$. The reflectivity of the filters is higher than $99.7 \%$ for the spectral ranges of about $8 \mathrm{~nm}$ below the cut-off wavelengths. The filters have a very small $(\ll 1 \%)$ absorption for almost the entirety of the spectral regimes. However on the edge of the photonic stop band (cut-off wavelength) the absorption can be up to $7 \%$ and $4 \%$ for the filters with cut-off wavelengths of 470 and $550 \mathrm{~nm}$. At this positon, the photon density reaches its maximum, which

\footnotetext{
${ }^{2}$ Omicron Laserage (CW Diode-Laser), laserproduckte $\mathrm{GmbH}$, Germany.

Power stability $<1 \% \mathrm{~h}^{-1}$, pointing stability $<10 \mu \mathrm{rad}$.

Beam diameter: 2.55 (perpendicular: $0^{\circ} \mathrm{mm}^{-1}$ ) and 2.53 (parallel: $90^{\circ} \mathrm{mm}^{-1}$ )

${ }^{3}$ Hamamatsu (H7421-50), Japan, count sensitivity: $2.1 \times$ $10^{5} \mathrm{~s}^{-1} \mathrm{pW}^{-1}$ at $550 \mathrm{~nm}$ and $3.9 \times 10^{5} \mathrm{~s}^{-1} \mathrm{pW}^{-1}$ at $800 \mathrm{~nm}$.
}

increases the probability of absorption of a photon. If this absorption at about the cut-off wavelength exists, then this can potentially amplify the luminescence. The fluorescence contamination is corrected using the background signal measurements. An optical system (Fig. 1, no. 10) based on photodiodes and a $\mathrm{NO}_{2}$-filled cuvette is installed to monitor the change in the wavelength and power of the diode laser. The stray light in the system is reduced to a minimum by using a combination of baffles. There are different types of baffles (Fig. 1, no. 11 and 12) used in the system to reduce scatter from walls or mirrors. The shape of a baffle surface is based on a zigzag pattern with a $30^{\circ}$ angle. The sharpened edges of a baffle provide less surface area for the laser light to scatter and have the characteristics of a light trap.

The diode laser has a Deepstar mode, which is used as an advantage for the system. While operating in this mode with the repetition rate of $5 \mathrm{MHz}$, there is no laser radiation during the off period and the $\mathrm{NO}_{2}$ fluorescence is detected during the laser-off period. To determine the optimum sensitivity as a function of the repetition range, the relative $\mathrm{NO}_{2}$ fluorescence intensities for different on-off cycles was calculated by taking into account key parameters like $\mathrm{NO}_{2}$ absorption cross section, pressure, flow velocity, fluorescence lifetime, and the power of the diode laser. The calculated sensitivity for different laser-on durations is shown in Fig. 2a based on $1 \mathrm{ppb}$ of $\mathrm{NO}_{2}$ as a function of an off-period duration. For a comparison to current operational on-off cycles, three different laser-on periods are shown in Fig. 2a. The best sensitivity of the instrument is achievable by operating the diode laser at $5 \mathrm{MHz}, 100 \mathrm{~ns}$ on, $100 \mathrm{~ns}$ off.

A counter card is used for the data acquisition. There is no need for synchronization as the counter card itself triggers the laser pulse. The timing system is entirely controlled by an FPGA (field programmable gate array), utilizing an external crystal oscillator of $20 \mathrm{MHz}$ nominal frequency with a stability of $\pm 2.5 \mathrm{ppm}$ over the temperature range of -30 to $+75^{\circ} \mathrm{C}$. All internal frequencies are derived from this clock by means of a PLL (phase-locked loop) in the FPGA. The triggering occurs at a fixed rate of $5 \mathrm{Mhz}$. The delay caused by the length of the trigger cable (propagation delay of the pulse), the laser power supply unit, propagation delays from detector to FPGA, etc. is compensated with a programmable delay for the data acquisition in the FPGA. Therefore, the FPGA logic recognizes when it should start recording the data after it emitted the trigger pulse and waits the specified amount of programmed clock cycles after emitting the trigger. The time-resolved raw signal (both on-off cycle) are stored in $4 \mathrm{~ns}$ bins $(4 \mathrm{~ns}$ bin $=1$ channel) for a specified time of integration (typically $1 \mathrm{~s}$ ). For the total fluorescence signal about 20 of these channels are summed up and used as a signal for $\mathrm{NO}_{2}$. The first five channels or $20 \mathrm{~ns}$ of the laser-off period are ignored because these channels still contain some scattered light signals from the laser light and walls of detection cell (Fig. 2b). 

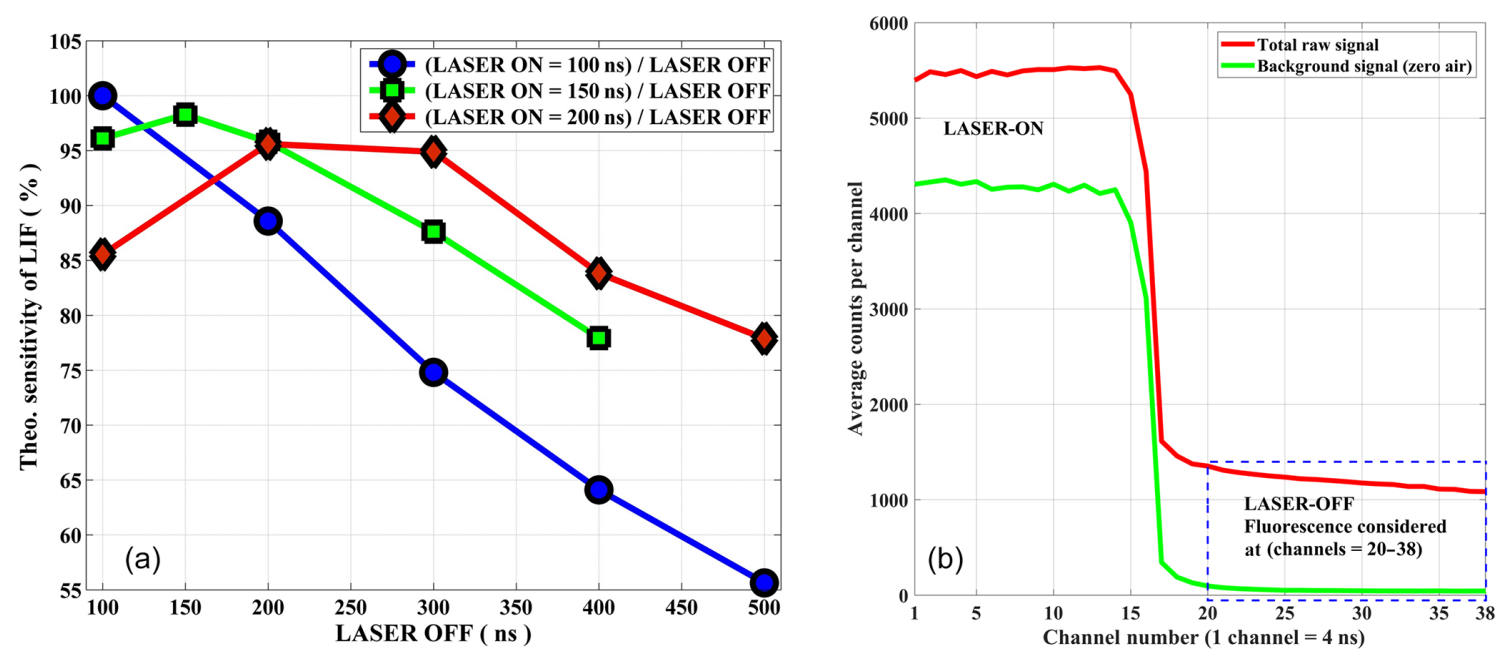

Figure 2. (a) Relative sensitivity of the instrument based on the simulation is demonstrated for three different on-off cycles of diode laser operation. (b) On-off cycle of the laser is shown for a signal of about 12 ppb NO 2 ( $y$ axis arb. unit). The sum of channels (20-38) is considered a fluorescence signal for the data analysis. A schematic of the data acquisition system is provided in the Supplement.

The surface temperatures of the PMT and laser are kept at 20 or $25^{\circ} \mathrm{C}$ (avoiding condensation) by circulating water. This provides the heat sink for the internal thermoelectric cooling of the PMT (@ $0^{\circ} \mathrm{C}$ ) and laser $\left(@ 25^{\circ} \mathrm{C}\right)$. The internal cooling is the default setting from the manufacturer. The internal temperature cannot be regulated by external cooling. The external temperature should be in the range of $5-35^{\circ} \mathrm{C}$ along a sufficient heat exchange system (fan cooling, water circulation, etc.). Moreover, the dark counts on the PMT signal are of the order of $<50$ counts s ${ }^{-1}$ for the channels used for the $\mathrm{NO}_{2}$ fluorescence detection. The major reason for the background signal, which is larger than the dark signal typically by a factor $>25$, is expected to be fluorescence contamination from the Herriot cell mirrors existing in the red region of wavelength. For a stable (parameters like power, wavelength, shape of the beam, etc.) laser operation, an external temperature range is within $15-30^{\circ} \mathrm{C}$. This range is sufficient to keep the internal temperature of the laser at $25^{\circ} \mathrm{C}$. A laser operation out of the specified range would lead to shut-off or potentially damage the laser.

\subsection{Calibration system}

The LIF method is not an absolute technique and requires calibration. The sensitivity (Eq. 1) of GANDALF depends on background noise, laser power or wavelength, temperature, pressure, residence time in the sampling line, etc. It is determined using $\mathrm{NO}_{2}$ concentrations generated by gas phase titration of $\mathrm{NO}$ to $\mathrm{NO}_{2}$ by means of $\mathrm{O}_{3}$ (Reaction R3) similar to the one described by Ryerson et al. (2000). Using commercial available $\mathrm{NO}_{2}$ gas cylinders at low concentrations (Thornton et al., 2000; Dari-Salisburgo et al., 2009) was not chosen due to open questions with its long-term stability at low concentration. The calibration system is described in the following sections.

The NO calibration mixture for the gas phase titration is traceable to a primary NIST (National Institute of Standards and Technology, USA) standard $\left(4.91 \pm 0.04 \mu \mathrm{mol} \mathrm{mol}^{-1}\right.$ in nitrogen). The overall uncertainty in the NO calibration mixture is $2 \%$. NO is almost completely (>98\%) consumed during gas phase titration with $\mathrm{O}_{3}$ in the calibrator. This is achieved by using a high concentration (> $1.4 \mathrm{ppm}$ ) of $\mathrm{O}_{3}$. $\mathrm{NO}_{2}$ also reacts with $\mathrm{O}_{3}$ to form $\mathrm{NO}_{3}$ (Reaction R4). The reaction of $\mathrm{NO}_{2}$ with $\mathrm{O}_{3}$ (Reaction $\mathrm{R} 4$ ) is slower by 3 orders of magnitude compared to the reaction of $\mathrm{NO}$ with $\mathrm{O}_{3}$ (Reaction $\mathrm{R} 3$ ), with a reaction rate of $3.5 \times 10^{-17} \mathrm{~cm}^{3}$ molecules ${ }^{-1} \mathrm{~s}^{-1}$ compared to $1.8 \times$ $10^{-14} \mathrm{~cm}^{3}$ molecules ${ }^{-1} \mathrm{~s}^{-1}$ at $298 \mathrm{~K}$ (Atkinson et al., 2004). However, at higher concentrations and due to the long residence times, the reaction between $\mathrm{NO}_{2}$ and $\mathrm{O}_{3}$ can be important, leading to a loss of $\mathrm{NO}_{2}$ generated in the calibrator with subsequent losses due to further reaction between $\mathrm{NO}_{2}$ and $\mathrm{NO}_{3}$ (Reaction R5).

$\mathrm{NO}+\mathrm{O}_{3} \rightarrow \mathrm{NO}_{2}+\mathrm{O}_{2}$
$\mathrm{NO}_{2}+\mathrm{O}_{3} \rightarrow \mathrm{NO}_{3}+\mathrm{O}_{2}$
$\mathrm{NO}_{2}+\mathrm{NO}_{3}+M \leftrightarrow \mathrm{N}_{2} \mathrm{O}_{5}+M$

Numerical simulations are used to assess the optimum set-up for the calibration device by studying the impact of different parameters like concentrations levels, residence time, flow rates, and pressure. Based on box model (BM) simulations and verified by lab experiments, a PFA (perfluoroalkoxy) reaction chamber for the completion of the gas phase titration between $\mathrm{NO}$ and $\mathrm{O}_{3}$ has been designed to achieve maximum conversion efficiency for $\mathrm{NO} \rightarrow \mathrm{NO}_{2}$. The $\mathrm{BM}$ simulation 

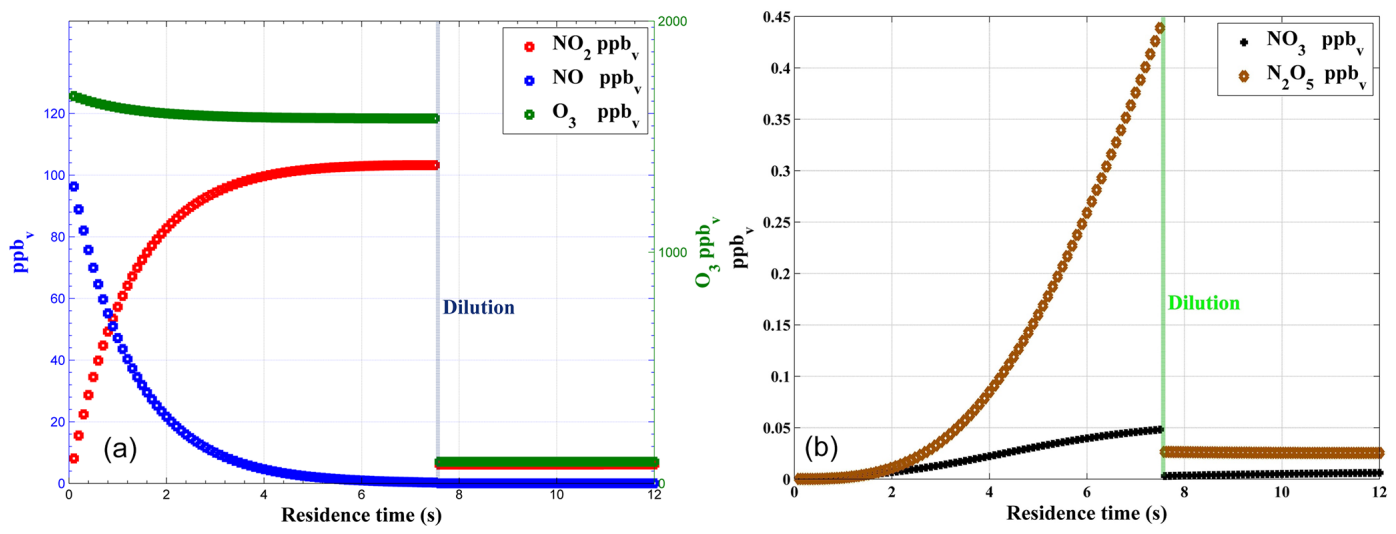

Figure 3. Box model simulation of gas phase titration of $\mathrm{NO}$ and $\mathrm{O}_{3}(\mathrm{a})$

(a) with loss of $\mathrm{NO}_{2}$ due to the formation of $\mathrm{NO}_{3}$ and $\mathrm{N}_{2} \mathrm{O}_{5}$ (b).

is shown in Fig. 3 for typical calibration parameters ${ }^{4}$. The mixing ratios of $\mathrm{NO}, \mathrm{O}_{3}$, and $\mathrm{NO}_{2}$ are plotted as a function of residence time in Fig. 3a. This simulation predicts that more than $99 \%$ of $\mathrm{NO}$ is converted to $\mathrm{NO}_{2}$ within the residence time of $7.5 \mathrm{~s}$ inside the reaction chamber. The formation of $\mathrm{NO}_{3}$ and $\mathrm{N}_{2} \mathrm{O}_{5}$ in the reaction chamber is negligible $(<0.5 \mathrm{ppb})$ compared to $\mathrm{NO}_{2}$ (>100 ppb). The formation of $\mathrm{NO}_{3}$ and $\mathrm{N}_{2} \mathrm{O}_{5}$ can thus only increase by $<1 \%$ uncertainty in the generated $\mathrm{NO}_{2}$ for typical operating conditions of the calibrator. After the reaction chamber, the calibration gas mixture is further diluted with zero air to achieve a required range (close to ambient levels) of $\mathrm{NO}_{2}$ mixing ratios.

The calibration system was tested for different concentrations of $\mathrm{O}_{3}$. Figure 4 shows the $\mathrm{NO}_{2}$ signal of the PMT (after dilution of the calibration gas) based on different $\mathrm{O}_{3}$ mixing ratios in the reaction chamber for a constant $\mathrm{NO}$ concentration (about $0.1 \mathrm{ppm}$ ). For $\mathrm{O}_{3}$ concentrations below $1 \mathrm{ppm}$ non-stoichiometric conversion of NO was observed as expected. The PMT signal reached a maximum at about $1.356 \mathrm{ppm}$ and this signal is explained by the derived $\mathrm{NO}_{2}$ concentration from the $\mathrm{BM}$ simulation. The decrease in the PMT signals at higher $\mathrm{O}_{3}$ concentrations above $1.4 \mathrm{ppm}$ mainly due to loss of $\mathrm{NO}_{2}$ in Reactions (R4) and (R5). The amount of $\mathrm{NO}_{2}$ generated in the $\mathrm{NO}+\mathrm{O}_{3}$ titration is much less sensitive to $\mathrm{O}_{3}$ than to $\mathrm{NO}$ as losses of $\mathrm{NO}_{2}$ (Reaction $\mathrm{R} 4$ ) are also dependent on $\mathrm{O}_{3}$ for the chosen parameters. If $\mathrm{O}_{3}$ is increased by $1 \mathrm{ppm}$ above the optimum mixing ratio of $1.3 \mathrm{ppm}$ (Fig. 4), $\mathrm{NO}_{2}$ is reduced by only $1 \%$. The $\mathrm{O}_{3}$ concentrations are always kept above this threshold limit and the concentrations are measured using an $\mathrm{O}_{3}$ analyser (ANSYCO, O3-41M, Analytische Systeme und Componenten $\mathrm{GmbH}$, Germany) with a typical precision of $5 \%$. Above the threshold, a $5 \%$ change in $\mathrm{O}_{3}$ produces an uncertainty in $\mathrm{NO}_{2}$ of less than $0.5 \%$.

\footnotetext{
${ }^{4}$ Initial parameters for this specific simulation: $\mathrm{NO}=5 \mathrm{sccm} \times$ $10.55 \mathrm{ppm}, \mathrm{O}_{3}=500 \mathrm{sccm} \times 1.7 \mathrm{ppm}$, residence time in the reaction chamber is $7.5 \mathrm{~s}$, flow is $8000 \mathrm{sccm}$, temperature and pressure are $298 \mathrm{~K}$ and $1013.25 \mathrm{hPa}$
}

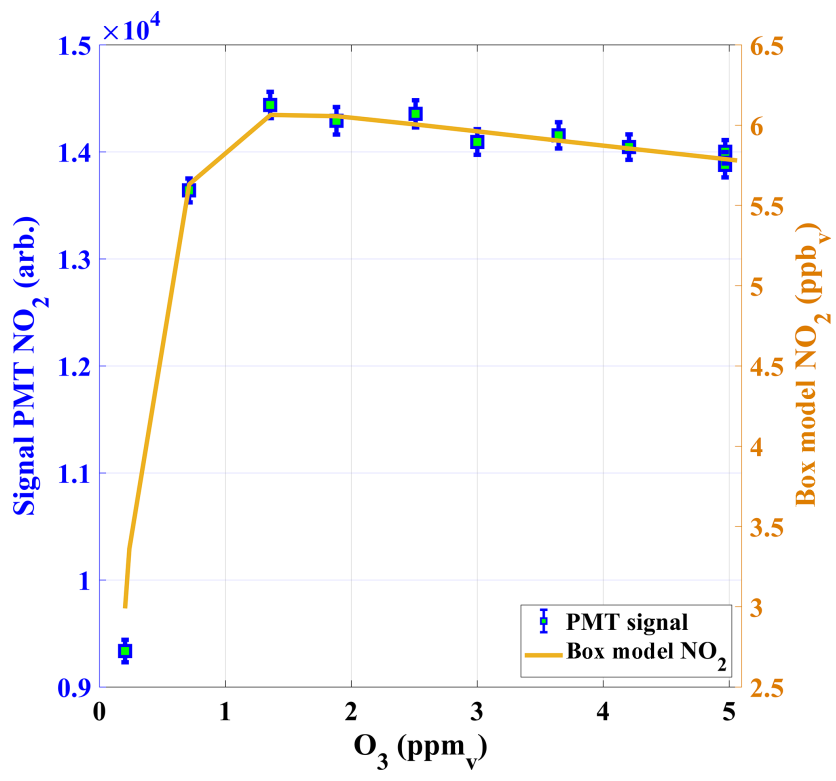

Figure 4. The PMT $\mathrm{NO}_{2}$ signals in counts (cts) are shown as a function of $\mathrm{O}_{3}$ concentrations in the calibrator (left $y$ axis), together with $\mathrm{NO}_{2}$ calculated from a box model of the $\mathrm{NO}_{2}$ production in the calibrator (right $y$ axis).

A $\mathrm{NO}_{x}$ analyser (model: ECO PHYSICS CLD 780 TR, Switzerland) was used to determine the remaining concentrations of NO inside the calibrator after the gas phase titration. About $99 \%$ of $\mathrm{NO}$ is consumed in the gas phase titration for most of the cases at $\mathrm{O}_{3}>1.4 \mathrm{ppm}$. There are two different regimes in the calibration system based on different NO and $\mathrm{O}_{3}$ concentrations and different flow rates: (1) gas phase titration in the reaction chamber and (2) dilution with zero air after the reaction chamber. Considering the flow rates and dimensions of the gas lines, the theoretically calculated total residence time based on the plug flow assumption is $7.73 \mathrm{~s}$. The total residence time for the calibration gas in the calibration system is also determined experimentally by using 
Eq. (3).

$$
\begin{aligned}
\mathrm{NO}_{\mathrm{GPT}} & =D\left[\mathrm{NO}_{\mathrm{i}}\right]\left(e^{-k_{(\mathrm{R} 3)}\left[\mathrm{O}_{3}\right] t_{1}}\right)\left(e^{-k_{(\mathrm{R} 3)}\left[\mathrm{O}_{3}\right] D t_{2}}\right) \\
& \Rightarrow\left[t_{1}+D t_{2}\right]=-\left[\frac{\ln \left(\frac{\mathrm{NO}_{\mathrm{GPT}}}{D\left[\mathrm{NO}_{\mathrm{i}}\right]}\right)}{k_{(\mathrm{R} 3)}\left[\mathrm{O}_{3}\right]}\right]
\end{aligned}
$$

In Eq. (3), $\mathrm{NO}_{\mathrm{GPT}}$ is measured with the $\mathrm{NO}_{x}$ analyser and is defined as the NO concentration remaining in the calibration gas after the gas phase titration and dilution. $\left[\mathrm{NO}_{\mathrm{i}}\right]$ is the initial concentration of $\mathrm{NO}$ before the gas phase titration. $D$ is the dilution factor after the reaction chamber. $t_{1}$ is the residence time for the reaction chamber and $t_{2}$ is the dilutiondependent travel time for a $\mathrm{NO}_{2}$ molecule from the exit of the reaction chamber to the inlet of GANDALF. $\left[\mathrm{O}_{3}\right]$ in Eq. (3) is the concentration in the reaction chamber. $k_{(\mathrm{R} 3)}$ is the temperature-dependent rate coefficient for Reaction (R3). There are two slightly different $(<6 \%$ based on rate constant at $298 \mathrm{~K}$ ) values reported in the literature for the temperaturedependent $k_{(R 3)}$ as follows:

$k_{(\mathrm{R} 3)}=3 \times 10^{-12} \times e^{\left(\frac{-1500}{T}\right)}$

$\left(1.9 \times 10^{-14} \mathrm{~cm}^{3}\right.$ molecules ${ }^{-1} \mathrm{~s}^{-1}$ at $\left.298 \mathrm{~K}\right)$

(Sander et al., 2011)

$k_{(\mathrm{R} 3)}=1.4 \times 10^{-12} \times e^{\left(\frac{-1310}{T}\right)}$

$\left(1.8 \times 10^{-14} \mathrm{~cm}^{3}\right.$ molecules ${ }^{-1} \mathrm{~s}^{-1}$ at $\left.298 \mathrm{~K}\right)$

(Atkinson et al., 2004).

Based on Eq. (3), the average value of total residence time $\left[t_{1}+D t_{2}\right]$ is $7.32 \pm 0.25 \mathrm{~s}$ (Sander et al., 2011) or $8.38 \pm 0.29 \mathrm{~s}$ (Atkinson et al., 2004) as shown in Fig. 5. The estimated accuracy of these two values for the total residence time is $6.5 \%(1 \sigma)$.

The temperature and pressure also affect the formation of $\mathrm{NO}_{2}$ inside the reaction chamber, and these effects were tested with the box model. In the simulations all parameters except temperature or pressure are kept constant. At a lower temperature the reaction between $\mathrm{NO}$ and $\mathrm{O}_{3}$ slows down, leading to changes in the conversion efficiency from $\mathrm{NO}$ to $\mathrm{NO}_{2}$. This can potentially lead to a change in the conversion efficiency from $\mathrm{NO}$ to $\mathrm{NO}_{2}$. In our case, many electrical parts (electronic valves, ozone generator, and mass flow controllers) are installed inside the calibration unit. In a fully operational mode for 1 day, the temperature build-up in the calibration unit is $8-10^{\circ} \mathrm{C}$ higher than ambient temperatures. From our experience and observations, conditions with temperatures lower than $20^{\circ} \mathrm{C}$ do not occur inside the calibrator. According to the box model simulations temperature variations within $5-45^{\circ} \mathrm{C}$ lead to an overall relative uncertainty of $1 \%(1 \sigma)$ for the whole range. Similarly, the impact on the calibration gas due to a change in the atmospheric pressure is not significant. Based on the box model simulations, the

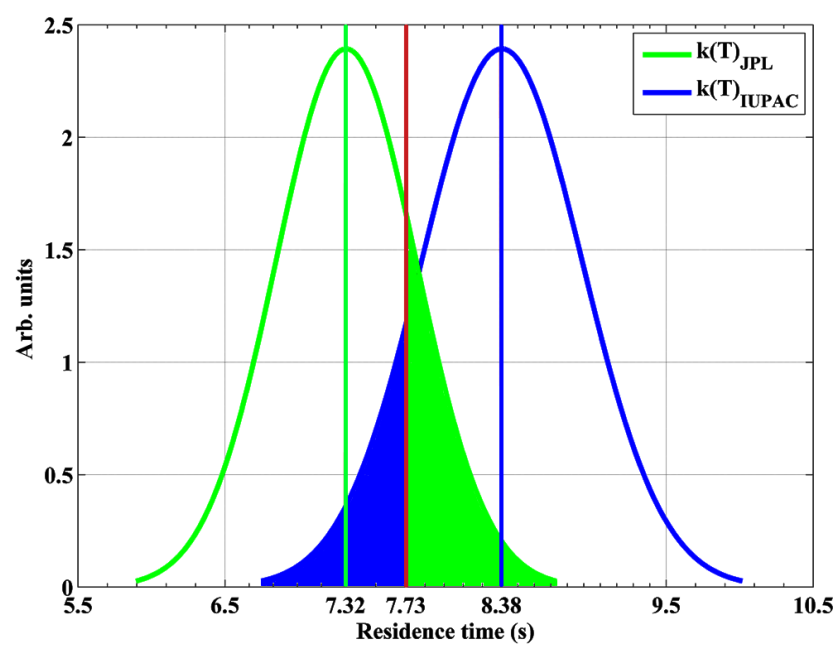

Figure 5. Residence time for $\mathrm{NO}_{2}$ calibration gas in the calibrator based on Eq. (3). Also, theoretically calculated residence time $(7.73 \mathrm{~s})$ is shown (red line). The likelihoods (green or blue shaded areas) of residence times based on the JPL or IUPAC rate constant for being accurate are indistinguishable in comparison to the theoretically calculated residence time.

relative uncertainty in the $\mathrm{NO}_{2}$ concentration of calibration gas is below $0.5 \%$ ( $1 \sigma$ due to a change in the atmospheric pressure over an interval of $800-1013 \mathrm{hPa}$ ).

The calibration gas for GANDALF primarily contains $\mathrm{N}_{2}$ $(\sim 79.5 \%)$ and $\mathrm{O}_{2}(\sim 20.5 \%)$ with $\mathrm{H}_{2} \mathrm{O}$ vapour $(<25 \mathrm{ppm})$. The level of $\mathrm{H}_{2} \mathrm{O}$ vapour in the atmosphere can reach up to about $3 \%$ (Seinfeld and Pandis, 2006). The sensitivity of the instrument is reduced by atmospheric $\mathrm{H}_{2} \mathrm{O}$ vapour because collisions with $\mathrm{H}_{2} \mathrm{O}$ molecules quench the $\mathrm{NO}_{2}$ fluorescence. The $\mathrm{H}_{2} \mathrm{O}$ dependency is evaluated experimentally by diluting the calibration gas with known amounts of water vapour concentrations and its effect on sensitivity during field measurements is corrected by using simultaneous measurements of $\mathrm{H}_{2} \mathrm{O}$ vapour in the atmosphere. The $\mathrm{H}_{2} \mathrm{O}$ concentrations during calibration are determined using an existing calibration system for the LIF-OH instrument (Martinez et al., 2010). The decrease (relative to $<25 \mathrm{ppm}$ of water vapour) in the sensitivity for GANDALF is $5 \% \pm 1 \%(1 \sigma)$ at $1 \%$ of atmospheric $\mathrm{H}_{2} \mathrm{O}$ vapour.

A robust calibration system has been developed for the automated calibration of the instrument. GANDALF is frequently calibrated (up to 8 times in $24 \mathrm{~h}$ ) during field operations to track changes in sensitivity. Generally, some factors can contribute to a change in the sensitivity, e.g. stability of the optics alignment, cleanness of the optics, temperaturerelated effect of electronics, and stability of the calibration signal. An example of a calibration plot is shown in Fig. 6. The calibration system is controlled by mass flow controllers (MFCs; MKS Instruments, USA, and Bronkhorst HIGH-TECH B.V, the Netherlands) and electronic valves (Solenoid Operated Diaphragm, Galtek, USA). All MFCs are 


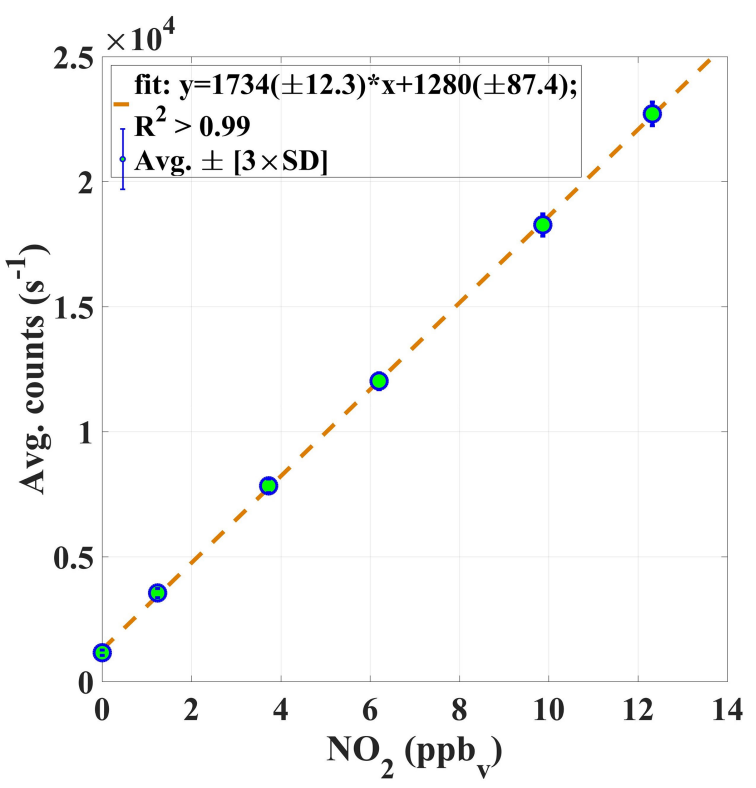

Figure 6. An example of the average PMT signal in counts $\left(\mathrm{s}^{-1}\right)$ vs. known mixing ratios of $\mathrm{NO}_{2}$. The calibration constant $\alpha_{\mathrm{c}}$ (Eq. 1) is given by the slope of the curve.

calibrated using a DryCal (DC-2, BIOS International Corporation, USA) sensor, which is traceable to a NIST standard (NIST traceability is confirmed by WESTPHAL measurement and control technique GmbH \& Co. KG, Germany). The uncertainty in the set flows, based on a certified value, is $1 \%$ (level of confidence $95 \%$ ). $\mathrm{O}_{3}$ is generated for the calibration using an ozone generator (SOG2, $185 \mathrm{~nm}$, Ultraviolet Products, USA). Different $\mathrm{NO}_{2}$ mixing ratios are achieved by changing the NO flow (range up to $10 \mathrm{sccm}$ ), while the $\mathrm{O}_{3}$ concentration $(>1.4 \mathrm{ppm})$ and flow $(500 \mathrm{sccm})$ are kept constant. Figure 7 shows a schematic of the set-up for the automated calibration procedure of GANDALF. A small pump (calibration pump) is connected to the main sampling line of GANDALF. A three-way electronic valve (EV2) and a manual needle valve (MNV) are attached in front of the calibration pump. To minimize any line effects such as a decomposition of species like PAN, the chemical reaction of the ambient $\mathrm{NO}$ and $\mathrm{O}_{3}$, the residence time in the sampling line is kept at less than $0.1 \mathrm{~s}$ by a flow $\geq 10000 \mathrm{sccm}$ required during ambient air measurements. GANDALF has a flow of $4100 \mathrm{sccm}$ through the pinhole and the rest of the flow is diverted to the main exhaust by the calibration pump. The amount of total sampling flow can be increased or decreased by adjusting the MNV.

During ambient air measurements, valve EV2 is opened for line L1 at the position P1 (Fig. 7) and allows an extra flow of about 8000-9000 sccm to pass from the sampling flow to the calibration pump. Line L1 is simultaneously used to condition the NO calibration line with a flow of $2 \mathrm{sccm}$ NO gas, which goes directly to the exhaust without entering the sam- pling line. The direction for the conditioning flow along the bypass flow is shown by the green arrow in Fig. 7 .

Frequent zero-air measurements are necessary to monitor changes in the background signal of GANDALF. A three-way electronic valve (EV3) and a mass flow controller (MFC zero) are used to switch the zero-air background flow $(8000 \mathrm{sccm})$ on and off in the line L3 (position P1 at EV3 in Fig. 7). During background signal measurements, an excess of zero air about $3900 \mathrm{sccm}$ (blue arrow in Fig. 7) is diverted to the calibration pump through line L1 by setting the valve EV2 to position P1, along with about $5100 \mathrm{sccm}$ flow of ambient air.

During calibration the zero-air flow is switched on (position P2 at EV3 in Fig. 7) and used for dilution of the calibration gas. Line L2 is opened by valve EV2 (position P2 at EV2 in Fig. 7) to remove the calibration gas overflow of $3900 \mathrm{sccm}$ together with $5100 \mathrm{sccm}$ from the ambient (illustrated by the red arrows in Fig. 7). For the gas phase titration, the flow of $\mathrm{O}_{3}$ is switched on and off by the two-way electronic valve EV1 and MFC $\left(\mathrm{O}_{3}\right)$. The $\mathrm{O}_{3}$ analyser is used to check the concentration of $\mathrm{O}_{3}$ produced by the ozone generator. The flow of NO $(1-10 \mathrm{sccm})$ is controlled by a mass flow controller (MFC (NO) in Fig. 7). Since all overflows are diverted to an exhaust, this set-up allows frequent checks of the GANDALF sensitivity and background signal without disturbing the ambient conditions for a nearby operating instrument. Based on calibrations during PARADE 2011, the repeatability of the sensitivity was $2.7 \%(1 \sigma)$, with an overall uncertainty in the calibration system of approx. $5 \%(1 \sigma)$.

\subsection{Precision and limit of detection}

The precision of the instrument was evaluated using a set of randomly chosen PMT signals (in $\mathrm{s}^{-1}$ time resolution) during calibration periods from the field experiment (PARADE 2011). The relative precision was calculated based on the standard deviation of the PMT $\mathrm{NO}_{2}$ signal for different $\mathrm{NO}_{2}$ concentrations. The relative precision of GANDALF is shown in Fig. 8 as a function of $\mathrm{NO}_{2}$ mixing ratios. It was better than $0.5 \%\left(1 \sigma \mathrm{min}^{-1}\right)$ for most of the dataset at $>1 \mathrm{ppb}$ of $\mathrm{NO}_{2}$. For an overall precision of GANDALF (especially at lower levels $<1 \mathrm{ppb}$ ), an absolute value of about $3 \mathrm{ppt}(1 \sigma)$ has to be added to the relative precision. This absolute value arises from the variations in the zero-air signal. The standard deviation of the PMT signals at different $\mathrm{NO}_{2}$ concentrations can be extrapolated to zero for determination of the precision at background levels. It can also be calculated from the standard deviation of the zero-air signal. The approaches give similar results of about $3 \mathrm{ppt}(1 \sigma)$ precision for our instrument.

The precision of the instrument background signal was also cross-checked using a continuous measurement of zero air for about $50 \mathrm{~min}$. In order to verify the square root dependency of the signal variability on integration time, an Allan deviation plot is used (Riley, 1995; Land et al., 2007). 


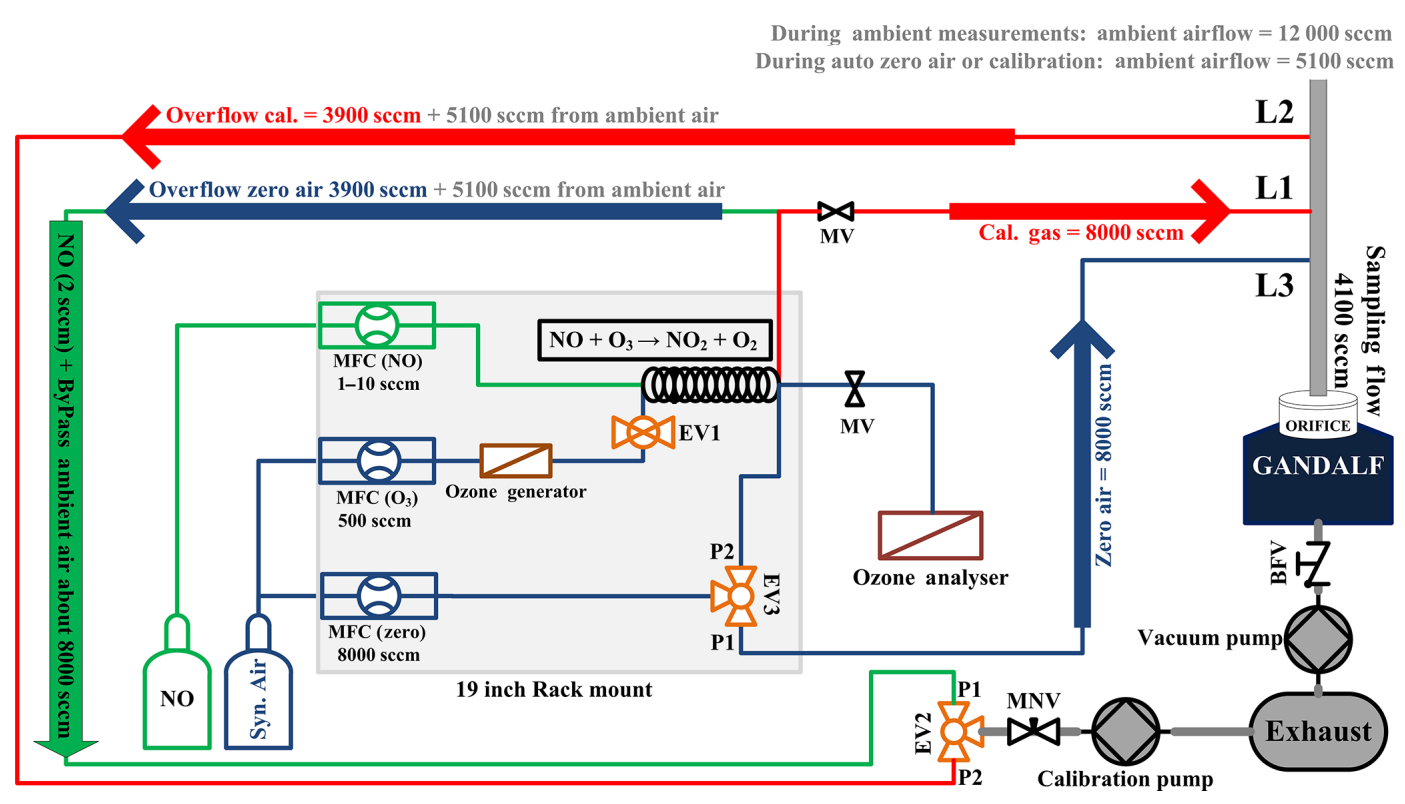

Figure 7. Schematic set-up for the automated calibrations during PARADE 2011.

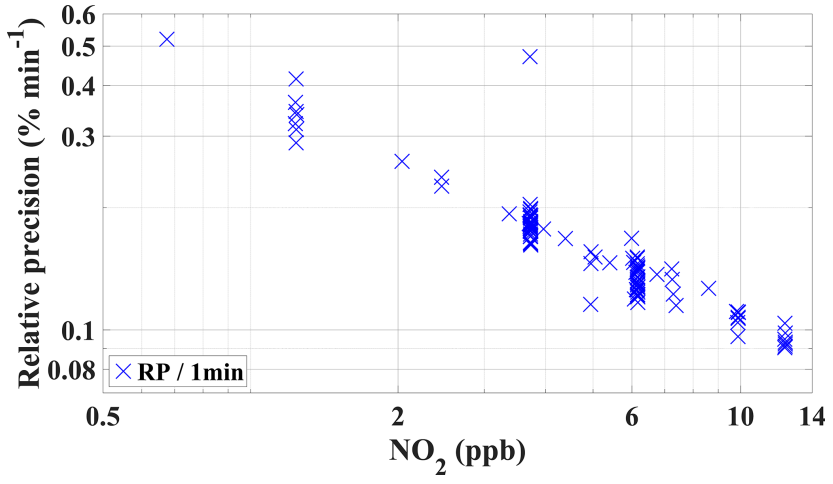

Figure 8. The relative $1 \mathrm{~min}$ precision of GANDALF is shown for PARADE 2011 as a function of $\mathrm{NO}_{2}$ mixing ratios. The relative precision is calculated from randomly selected PMT signals during different calibration periods.

Figure 9 shows an overlapping (Riley, 2008) Allan deviation plot of variations in background signal vs. averaging time. The variations in background signal with a $60 \mathrm{~s}$ integration time are equivalent to an absolute $\mathrm{NO}_{2}$ value of about $3 \mathrm{ppt}$ $(1 \sigma)$. Figure 9 also shows that the random noise of the instrument background signal can be reduced by averaging, with a square root dependency on time, at least up to a $60 \mathrm{~s}$ period. The background signal of GANDALF is frequently checked during a field operation (e.g. during PARADE; 1 background signal measurement per hour).

The limit of detection (LOD) can be derived from the variation in the background signals. Based on the Allan deviation plot in Fig. 9, a limit of detection of about 3 ppt $(1 \sigma) \mathrm{NO}_{2}$ for $1 \mathrm{~min}$ averaged measurements is expected. The stated

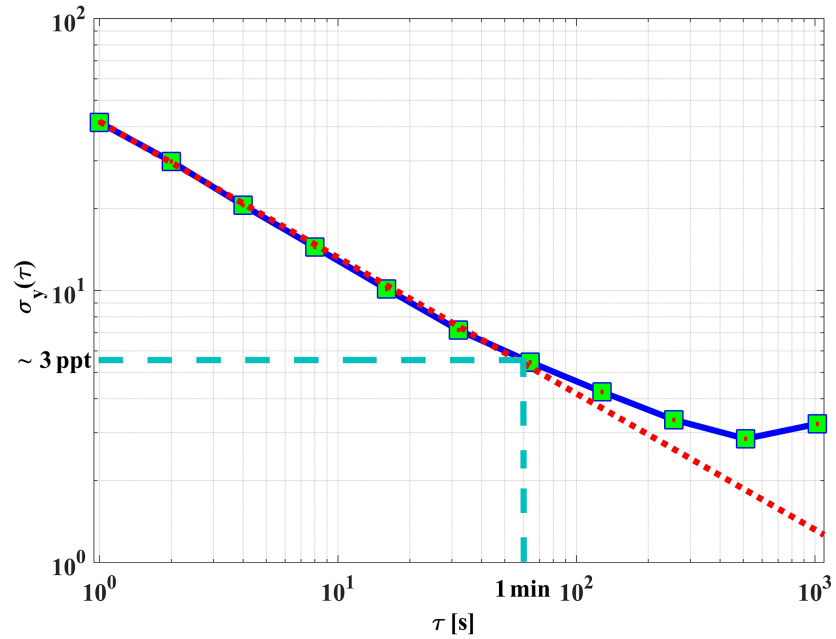

Figure 9. An overlapping Allan deviation plot for the dependence of the $1 \sigma$ variation in the background signal vs. integration time. The red dotted line shows the square root dependency of the signal.

(Table 1) LOD of GANDALF was calculated using Eq. (4) (Taketani et al., 2007) at a signal-to-noise ratio SNR of 2 and considering the background signal that is 2 times higher.

$\mathrm{LOD}=\frac{\mathrm{SNR}}{\alpha_{\mathrm{c}}} \sqrt{\frac{2 \times S_{\mathrm{BG}}}{t}}$,

where $\alpha_{\mathrm{c}}$ is the calibration factor or sensitivity in counts $\left(\mathrm{s}^{-1} \mathrm{ppb}^{-1}\right), S_{\mathrm{BG}}$ is the background signal in counts $\left(\mathrm{s}^{-1}\right)$ and $t$ is the averaging time in seconds. The LOD for GANDALF, based on sensitivity and background measurements during the field experiment (PARADE 2011), varied between 5 and 10 ppt. 


\subsection{Interferences by other species}

Several atmospheric gas species can absorb the $449 \mathrm{~nm}$ laser light inside the detection cell. This can lead to interference for the $\mathrm{NO}_{2}$ measurements with GANDALF directly (photodissociation process) or indirectly (fluorescence).

Iodine monoxide (IO) has an absorption cross section of $3.9 \times 10^{-18} \mathrm{~cm}^{2}$ molecules ${ }^{-1}$ (Harwood et al., 1997) and is about a factor of 8 larger than the $\mathrm{NO}_{2}$ absorption cross section at $449 \mathrm{~nm}$. Even a few ppt of IO in the atmosphere can produce a significant fluorescence signal, especially in the marine atmosphere, for which IO is mostly reported (Commane et al., 2011). The fluorescence lifetime of IO is only 1-10 ns (Bekooy et al., 1983; Newman et al., 1998). As described earlier, the initial $20 \mathrm{~ns}$ fluorescence signal is ignored in the GANDALF data evaluation. Therefore, the IO fluorescence signal after $20 \mathrm{~ns}$ becomes too small to significantly interfere with the $\mathrm{NO}_{2}$ fluorescence signal.

Nitrogen-containing inorganic species $\left(\mathrm{NO}_{3}, \mathrm{~N}_{2} \mathrm{O}_{5}\right.$, $\mathrm{HONO}_{2}, \mathrm{HO}_{2} \mathrm{NO}_{2}, \mathrm{PAN}, \mathrm{ClONO}, \mathrm{ClNO}_{2}$, and $\mathrm{ClONO}_{2}$ ) can produce $\mathrm{NO}_{2}$ by photo-dissociation, which can happen inside the detection cell. $\mathrm{N}_{2} \mathrm{O}_{5}$ (Harwood et al., 1993), $\mathrm{HONO}_{2}$ (Burkholder et al., 1993), $\mathrm{HO}_{2} \mathrm{NO}_{2}$ (Singer et al., 1989) PAN (Talukdar et al., 1995), and ClONO (Molina and Molina, 1977) are not known to photo-dissociate at this wavelength. The absorption cross sections for $\mathrm{ClONO}_{2}$ (Molina and Molina, 1979) and $\mathrm{ClNO}_{2}$ (Ghosh et al., 2012) are smaller by about 4 orders of magnitude compared to that of $\mathrm{NO}_{2}$ at $449 \mathrm{~nm}$. The tropospheric concentrations of $\mathrm{ClONO}_{2}$ and $\mathrm{ClNO}_{2}$ are generally smaller or similar compared to ambient $\mathrm{NO}_{2}$. Hence, an interference from these species is highly unlikely.

$\mathrm{NO}_{3}$ has a larger absorption cross section (Wayne et al., 1991) at $449 \mathrm{~nm}$ compared to the previously described nitrogen-containing species. The effective absorption cross section, calculated from (Wayne et al., 1991), is about a factor of 2 smaller than that of $\mathrm{NO}_{2}$ at the wavelength of the diode laser. The recommended quantum yield for the photodissociation of $\mathrm{NO}_{3}$ to $\mathrm{NO}_{2}+\mathrm{O}$ is about 1 at wavelengths below $585 \mathrm{~nm}$ (Sander et al., 2011); hence, its fluorescence (Wood et al., 2003) is insignificant compared to its photodissociation to $\mathrm{NO}_{2}$. Interference from photo-dissociation of $\mathrm{NO}_{3}$ is therefore a two-photon process:

First step: $\mathrm{NO}_{3}+h v_{\text {DiodeLaser }} \rightarrow \mathrm{O}+\mathrm{NO}_{2}$;

Second step: $\mathrm{NO}_{2}+h v_{\text {DiodeLaser }} \rightarrow \mathrm{NO}_{2}^{*} \rightarrow \mathrm{NO}_{2}+h v$.

The lifetime of $\mathrm{NO}_{3}$ can be estimated from Eq. (5).

$\tau\left(\mathrm{NO}_{3}\right) \approx \int \sigma_{\mathrm{NO}_{3}}(\lambda, T) \times \varphi_{\mathrm{NO}_{3}}(\lambda, T) \times F(\lambda, t) \mathrm{d} \lambda$,

where $\sigma(\lambda, T)$ is the effective absorption cross section of $\mathrm{NO}_{3}$ which is $2.7 \times 10^{-19} \mathrm{~cm}^{2}$ molecules ${ }^{-1} ; \varphi(\lambda, T)$ is the quantum yield for $\mathrm{NO}_{3}$, and $F(\lambda, t)$ is the photon flux from the diode laser of about $10^{20}$ photons $\mathrm{cm}^{-2} \mathrm{~s}^{-1}$. The residence time of sampling air in the effective beam area of the laser is much smaller $(<0.001 \mathrm{~s})$ compared to the $\mathrm{NO}_{3}$ photo-dissociation lifetime ( $>0.01 \mathrm{~s})$. Due to this reason, any chance of a significant interference from the $\mathrm{NO}_{3}$ photodissociation is highly unlikely. Moreover, the ratio of the atmospheric concentration between $\mathrm{NO}_{2}$ and $\mathrm{NO}_{3}$ is very high; e.g. during PARADE the median ratio $\mathrm{NO}_{2} / \mathrm{NO}_{3}$ was 430 for $\mathrm{NO}_{3}>0$ with a minimum value of 12 .

Alkenes and aromatics (aldehydes and benzene) are also abundant in the troposphere. However, absorption of alkenes and aromatics occurs in the UV range $(<300 \mathrm{~nm})$ (KellerRudek et al., 2013), well below the wavelengths used in GANDALF. Some carbonyls like glyoxal (CHOCHO) and methylglyoxal $\left(\mathrm{CH}_{3} \mathrm{COCOH}\right)$ also have absorption in the blue region of the visible spectrum. The absorption cross section values of $\mathrm{CHOCHO}$ and $\mathrm{CH}_{3} \mathrm{COCOH}$ are $5.28 \times$ $10^{-20} \mathrm{~cm}^{2}$ molecule ${ }^{-1}$ (Horowitz et al., 2001) and $9.26 \times$ $10^{-20} \mathrm{~cm}^{2}$ molecule ${ }^{-1}$ (Meller et al., 1991; Staffelbach et al., $1995)$ at $449 \mathrm{~nm}$, factors of about 10 and 5 smaller than the $\mathrm{NO}_{2}$ absorption cross section. Also, the fluorescence from these species is not known to be present in the region of $\mathrm{NO}_{2}$ fluorescence. Therefore, the interference from these species is not important.

To minimize the impact (prior to the orifice) of heterogeneous or thermal conversion of species like PAN (lifetime ${ }^{5}$ $\approx 2327 \mathrm{~s}$ ), $\mathrm{HO}_{2} \mathrm{NO}_{2}$ (lifetime $\approx 16 \mathrm{~s}$ ), $\mathrm{CH}_{3} \mathrm{OONO}_{2}$ (lifetime $\approx 0.3 \mathrm{~s}$ ), and $\mathrm{N}_{2} \mathrm{O}_{5}$ (lifetime $\approx 22 \mathrm{~s}$ ) yielding $\mathrm{NO}_{2}$, a short residence time of $<0.1 \mathrm{~s}$ is generally used by keeping the sampling flow high, e.g. $12000 \mathrm{sccm}$ in a $0.5 \mathrm{~m}$ long sampling line with a $4 \mathrm{~mm}$ internal diameter during PARADE 2011. After the orifice, the cell pressure is about $7 \mathrm{hPa}$ and this would lead to increase the lifetime of above-specified species even further, whereas the residence time after the orifice is less than $30 \mathrm{~ms}$. Therefore, a chance of interference in the low-pressure region from the thermal conversion is highly unlikely. An intercomparison of GANDALF and other measurements of $\mathrm{NO}_{2}$ during PARADE 2011 was conducted to look for systematic dependencies of the differences between the different measurements on several measured atmospheric quantities. No evidence of a potential interference has been found for GANDALF (Sect. 3.2).

\section{Field experiment: PARADE 2011}

The PARADE, PArticles and RAdicals: Diel observations of the impact of urban and biogenic Emissions, field experiment took place at the Taunus Observatory on Kleiner Feldberg ( $825 \mathrm{~m}$ a.s.l. (above sea level); $50.22^{\circ} \mathrm{N}, 8.45^{\circ} \mathrm{E}$ ) in Germany from 15 August (DOY, day of year 2011, =226) to 10 September $(\mathrm{DOY}=252) 2011$. The general focus of

\footnotetext{
${ }^{5}$ The lifetime is calculated from an IUPAC rate coefficient (temperature $=298 \mathrm{~K}$ and pressure $=1 \mathrm{bar}$ ) for the sampling line before the orifice.
} 
PARADE was to characterize summertime biogenic emissions and photochemistry in a forested environment with anthropogenic influence. The observatory is located in the vicinity of the Taunus region at the hilltop of Kleiner Feldberg. A total area of $5 \mathrm{~km}$ radius around the observatory is dominated by coniferous, broadleaved and mixed forest. The measurement platform was located at the top of the observatory. The site is often affected by anthropogenically influenced air from nearby cities such as Frankfurt (Main) (30 km SE), Wiesbaden (20 km SW), Mainz (25 km SSW), and some roads within $5-10 \mathrm{~km}$, depending on the wind direction. The temperature during PARADE varied within a range of $5-28^{\circ} \mathrm{C}$ with an overall average of $14.8^{\circ} \mathrm{C}$. The temperature conditions during PARADE can be subdivided into two phases. The periods of DOY $=226-237$ and 243246 for PARADE were slightly warmer and the temperature mostly stayed above $15^{\circ} \mathrm{C}$, whereas during the other periods of DOY $=238-242$ and 248-252 the temperature was below $15{ }^{\circ} \mathrm{C}$. The relative humidity $(\mathrm{RH})$ had an overall average value of $77 \%$ and variations within the interval of $37-$ $100 \%$. There were several episodes of rain during PARADE. In the later part of the campaign, fog persisted in the early morning hours. Air masses at the observatory arrived predominantly from the southwest (SW) to the northwest (NW) side of Kleiner Feldberg. Sampling lines for most of the trace gas monitoring instruments were located within a $5 \mathrm{~m}^{2}$ area at the top of the platform. The platform was about $8 \mathrm{~m}$ above ground and the top of the platform was above the forest canopy. An overview of the instrumentation and conditions during PARADE can be found, e.g. in Phillips et al. (2012) and Bonn et al. (2014). Note that all data sets for analysis are based on available 10 min averages.

\section{1 $\mathrm{NO}_{2}$ intercomparison during PARADE}

$\mathrm{NO}_{2}$ concentrations were measured with eight different instruments. Six out of eight instruments sampled at the top of the platform. The measurement techniques, uncertainties, time resolutions and LOD are summarized in Table 2 for the instruments located on the platform. The average ambient concentrations of $\mathrm{NO}_{2}$ during PARADE were approx. 2$3 \mathrm{ppb}$ with a range of approx. 0.13 to $22 \mathrm{ppb}$. $\mathrm{NO}_{2}$ instruments listed in Table 2 represent in situ measurement techniques with the exception of the LP-DOAS (long-path differential optical absorption spectroscopy).

A median value (based on 10 min averages) of the atmospheric $\mathrm{NO}_{2}$ concentration is derived from the $\mathrm{NO}_{2}$ measurements of all individual instruments at the platform, including LP-DOAS. For a valid correlation between the derived median $\mathrm{NO}_{2}$ and individual $\mathrm{NO}_{2}$ measurements, only those values of the median $\mathrm{NO}_{2}$ were selected, for which simultaneous data for all $\mathrm{NO}_{2}$ measurements were available. Figure 10 shows the correlation between individual $\mathrm{NO}_{2}$ measurements and the derived median $\mathrm{NO}_{2}$ concentrations. The total uncertainties of individual instruments are shown as error bars on the $y$ axis, while horizontal bars represent the standard deviation of the derived median $\mathrm{NO}_{2}$. The regression is done by using a bivariate fit according to the method described in York et al. (2004) and Cantrell (2008).

LP-DOAS: This instrument is based on traditional differential optical absorption spectroscopy (DOAS) (Platt et al., 1979; Perner and Platt, 1979) and follows the BeerLambert law. DOAS allows direct and absolute measurements of multiple trace gases in the atmosphere by using the distinct absorption band structure of the specific molecule (i.e. calibration is not needed) (Platt and Stutz, 2008). LP-DOAS is based on active remote sensing and requires an artificial light source (Pöhler et al., 2010). It provides an average concentration of $\mathrm{NO}_{2}$ or other trace gases through quantitative detection using the absorption over a light path of typically a few kilometres. The instrument in this study is a wellestablished instrument and has been a part of many field campaigns (Pöhler et al., 2010). During PARADE, the optical path length was approximately $2.5 \mathrm{~km}$ and the light source, as well as the spectrograph, was located on the platform. The optical retro-reflector reflecting the light back to the telescope was located on the mountain Großer Feldberg (distance of $1.23 \mathrm{~km}$ and height of $37 \mathrm{~m}$ ). Therefore the LP-DOAS measurement delivers values integrated along a $1.2 \mathrm{~km}$ straight line starting at the platform to the retro-reflector. The correlation $\left(R^{2}=0.96\right)$ plot between LP-DOAS and the derived median $\mathrm{NO}_{2}$ values is shown in Fig. 10c. The slope of the fit is $1.02 \pm 0.005$ with a negligible $y$ intercept of $-0.002 \pm 0.009 \mathrm{ppb}$ and these values are within the uncertainty in the instrument. The uncertainty in LPDOAS is mainly due to errors in the absorption cross sections of $\mathrm{NO}_{2}$. A larger scatter between the LP-DOAS to the in situ instruments is expected due to the sampling of different air masses (A1 in Fig. 11).

CE-DOAS: Cavity-enhanced DOAS (Platt et al., 2009) measurements of $\mathrm{NO}_{2}$ were also available during PARADE. This method is based on differential optical absorption spectroscopy (DOAS) combined with a cavity and provides in situ measurements of trace gases (Platt et al., 2009). CE-DOAS (cavity-enhanced differential optical absorption spectroscopy) requires calibration of the absorption light path in the cavity. This was performed with the measurement of two different Rayleigh absorbers (Helium, and air) according to Washenfelder et al. (2008). The campaign was also the first field trial for this instrument, with a reported error of measurements in the range of 5\%-10\%, mainly due to the accuracy of the light path calibration. The CE-DOAS and the CRDS shared the same sampling line. The slope and the $y$ intercept for CE-DOAS vs. the derived median $\mathrm{NO}_{2}$ are $0.92 \pm 0.007$ and $-0.032 \pm 0.01 \mathrm{ppb}$, with $R^{2}=1$ as shown in Fig. 10f. The difference from the 

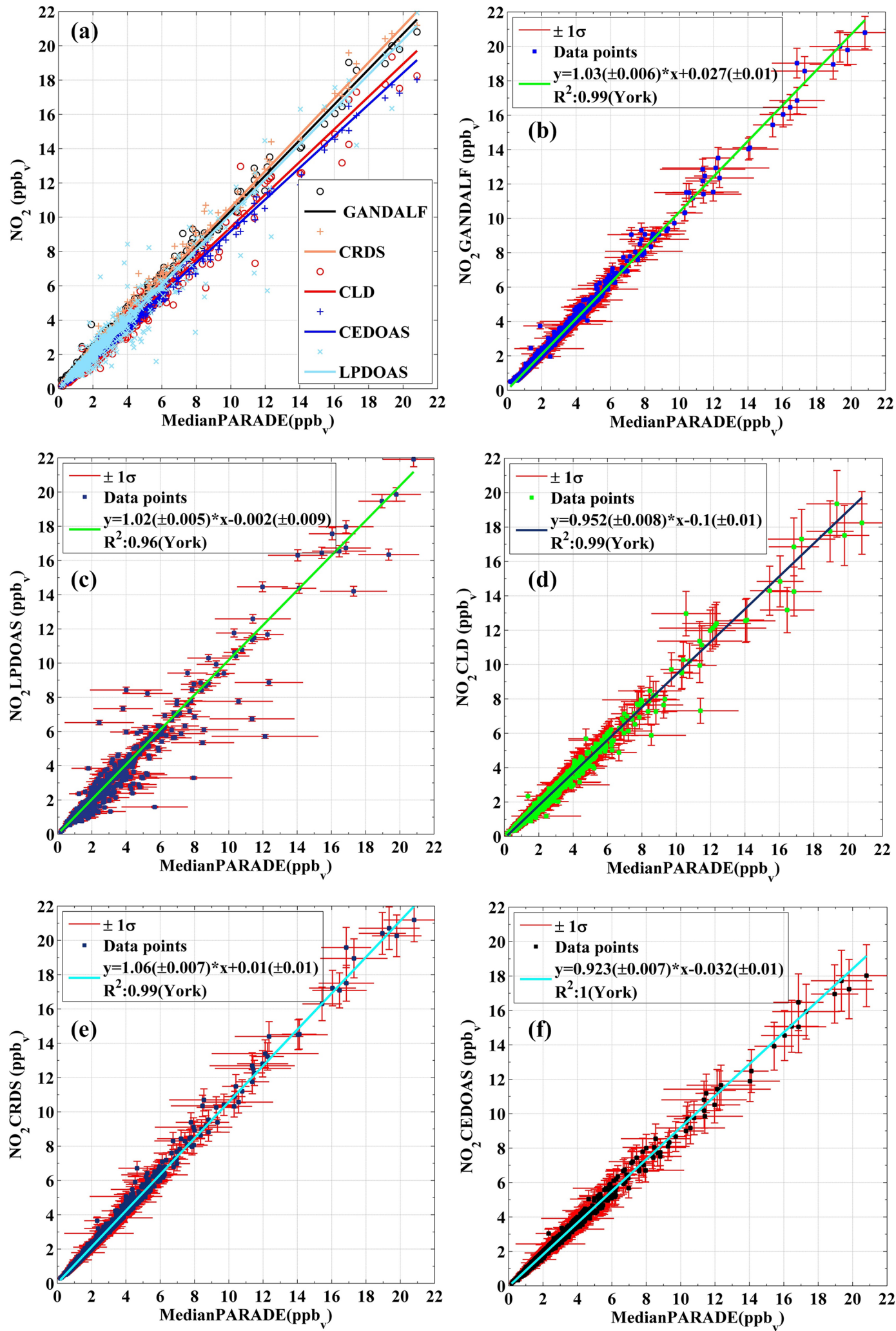

Figure 10. Correlation plots of individual $\mathrm{NO}_{2}$ measurement vs. the derived median values of all $\mathrm{NO}_{2}$ measurement at the platform during PARADE. (a) Overall, (b) GANDALF, (c) CLD, (d) CRDS, (e) LP-DOAS, and (f) CE-DOAS. 
Table 2. $\mathrm{NO}_{2}$ instruments located or sampling at the top of the platform during PARADE 2011.

\begin{tabular}{lllll}
\hline $\begin{array}{l}\text { Measurement } \\
\text { (operator) }\end{array}$ & Technique & Uncertainty & Detection limit & $\begin{array}{l}\text { Time } \\
\text { resolution }\end{array}$ \\
\hline $\begin{array}{l}\text { LP-DOAS } \\
\text { (IUP-HD) }\end{array}$ & Long-path DOAS & $2 \%$ & $\begin{array}{l}\text { Avg. }=110 \mathrm{ppt} \\
(11 \mathrm{~s}, 2 \sigma)\end{array}$ & $13 \mathrm{~s}$ \\
\hline $\begin{array}{l}\text { CE-DOAS } \\
\text { (IUP-HD) }\end{array}$ & Cavity-enhanced DOAS & $5 \%-10 \%$ & $\begin{array}{l}300 \mathrm{ppt} \\
(30 \mathrm{~s}, 2 \sigma)\end{array}$ & $2 \mathrm{~s}$ \\
\hline $\begin{array}{l}\text { CRDS } \\
\text { (MPIC) }\end{array}$ & $\begin{array}{l}\text { Cavity ring-down } \\
\text { spectrometer }\end{array}$ & $6 \% ; 20 \mathrm{ppt}$ & $\begin{array}{l}50 \mathrm{ppt} \\
(4 \mathrm{~s}, 2 \sigma)\end{array}$ & $4 \mathrm{~s}$ \\
\hline $\begin{array}{l}\text { CLD (BLC) } \\
\text { (MPIC) }\end{array}$ & $\begin{array}{l}\text { Chemiluminescence detector/ } \\
\text { Blue-light convertor }\end{array}$ & $105 \mathrm{ppt} ; 10 \%$ & $\begin{array}{l}55 \mathrm{ppt} \\
(2 \mathrm{~s}, 1 \sigma)\end{array}$ & $2 \mathrm{~s}$ \\
\hline $\begin{array}{l}\text { GANDALF } \\
\text { (MPIC) }\end{array}$ & Laser-induced fluorescence & $5 \%+11 \mathrm{ppt}(1 \sigma)$ & $\begin{array}{l}5-10 \mathrm{ppt} \\
(1 \mathrm{~min}, \mathrm{SNR}=2)\end{array}$ & $1 \mathrm{~s}$ \\
\hline
\end{tabular}

Table 3. Fit parameters based on the bivariate model function according to the relation $\left(\mathrm{NO}_{2}\right.$ instruments $=a \times\left[\right.$ median $\left.\left.\mathrm{NO}_{2}\right]+b\right)$ at different $\mathrm{NO}_{2}$ ranges. The value of $\mathrm{NO}_{2}$ instrument intercept $b$ is in ppb. $N$ is number of data points and $R^{2}$ is the square correlation coefficient. $\pm \delta$ is the standard error of slope $a$ and intercept $b$.

\begin{tabular}{|c|c|c|c|c|c|c|c|c|c|c|c|c|}
\hline \multirow[t]{2}{*}{$\mathrm{NO}_{2}$ instruments } & $a$ & $\pm \delta_{a}$ & $b$ & $\pm \delta_{b}$ & $N$ & $R^{2}$ & $a$ & $\pm \delta_{a}$ & $b$ & $\pm \delta_{b}$ & $N$ & $R^{2}$ \\
\hline & \multicolumn{6}{|c|}{$\mathrm{NO}_{2}<1 \mathrm{ppb}$} & \multicolumn{6}{|c|}{$\mathrm{NO}_{2} \geq 1$ to $\leq 6 \mathrm{ppb}$} \\
\hline LP-DOAS & 1.23 & 0.07 & -0.15 & 0.05 & 208 & 0.80 & 1.03 & 0.008 & -0.03 & 0.01 & 964 & 0.90 \\
\hline CE-DOAS & 0.95 & 0.06 & -0.06 & 0.05 & 208 & 0.80 & 0.92 & 0.01 & -0.03 & 0.02 & 964 & 0.99 \\
\hline CRDS & 1.1 & 0.07 & -0.02 & 0.05 & 208 & 0.83 & 1.06 & 0.01 & 0.002 & 0.02 & 964 & 0.99 \\
\hline CLD & 0.99 & 0.08 & -0.12 & 0.06 & 208 & 0.73 & 0.97 & 0.01 & -0.13 & 0.02 & 964 & 0.98 \\
\hline \multirow[t]{2}{*}{ GANDALF } & 1.06 & 0.07 & 0.015 & 0.05 & 208 & 0.74 & 1.04 & 0.01 & 0.015 & 0.02 & 964 & 0.99 \\
\hline & \multicolumn{6}{|c|}{$\mathrm{NO}_{2}>6$ to $<12 \mathrm{ppb}$} & \multicolumn{6}{|c|}{$\mathrm{NO}_{2} \geq 12 \mathrm{ppb}$} \\
\hline LP-DOAS & 1.2 & 0.08 & -1.51 & 0.6 & 52 & 0.64 & 1.42 & 0.2 & -6.64 & 4 & 15 & 0.69 \\
\hline CE-DOAS & 0.91 & 0.09 & 0.075 & 0.7 & 52 & 0.94 & 0.87 & 0.2 & 0.55 & 3 & 15 & 0.96 \\
\hline CRDS & 1.09 & 0.09 & -0.16 & 0.6 & 52 & 0.94 & 1.04 & 0.2 & 0.38 & 3 & 15 & 0.94 \\
\hline CLD & 1.02 & 0.1 & -0.64 & 0.7 & 52 & 0.81 & 0.89 & 0.2 & 0.51 & 3 & 15 & 0.84 \\
\hline GANDALF & 1.05 & 0.08 & 0.016 & 0.6 & 52 & 0.94 & 0.99 & 0.2 & 0.52 & 3 & 15 & 0.94 \\
\hline
\end{tabular}

median value is well within the range of instrumental uncertainty in this prototype. A further development of this prototype is the ICAD (iterative cavity-enhanced DOAS) from Airyx GmbH.

CRDS: Besides the DOAS instruments, another $\mathrm{NO}_{2}$ measurement technique was available using a cavity ringdown spectrometer (CRDS) (Thieser et al., 2016). CRDS is a cavity-assisted method like CE-DOAS (Platt et al., 2009). It is a direct method for in situ measurements which requires no calibration but only the background (zero air) measurements. In CRDS, reflective mirrors are used across an optical cavity. To obtain the concentration of a trace gas with CRDS, absorption measurements are made in the optical cavity to determine the time constant for exponential decay of the light intensity with and without an absorber. During PARADE, the instrument inlet was located $2 \mathrm{~m}$ above the platform. A PFA tube about $8 \mathrm{~m}$ long was used for the sampling air. The slope and $y$ intercept in the case of CRDS are $1.06 \pm 0.007$ and $0.01 \pm 0.01 \mathrm{ppb}$ with correlation $R^{2}=0.99$ as shown in Fig. 10e. The reported upper limit of uncertainty in the case of CRDS is $[6 \%+20 \mathrm{ppt}+(20 \mathrm{ppt} \times \mathrm{RH} / 100)]($ Thieser et al., 2016). The differences between CRDS and the derived median $\mathrm{NO}_{2}$ values are smaller than the instrument errors.

CLD/blue-light converter (BLC): Along with the abovementioned absolute methods, the concentrations of $\mathrm{NO}_{2}$ and NO were determined with a two-channel chemiluminescence detector (CLD). The instrument sampled air via $\sim 8 \mathrm{~m}$ long PFA tubing at $2 \mathrm{~m}$ above the platform. The CLD instrument of MPIC is well established, being an improved version (Hosaynali Beygi et al., 2011) of the ECO-Physics CLD 790 SR. In this instrument, $\mathrm{NO}_{2}$ is detected by conversion via photolysis to 
NO, using a blue-light converter at the wavelength of $395 \mathrm{~nm}$, with subsequent detection of NO by chemiluminescence. The calibration of the system is done by using gas phase titration between $\mathrm{NO}$ and $\mathrm{O}_{3}$ to produce stoichiometric quantities of $\mathrm{NO}_{2}$. The correlation $\left(R^{2}=0.99\right)$ between CLD and the derived median $\mathrm{NO}_{2}$ values is shown in Fig. 10d. Overall, the data on the CLD are about $5 \%$ below the median, but this difference is within the uncertainty in the CLD measurement. The reported uncertainty in the CLD for the $\mathrm{NO}_{2}$ measurements is 105 ppt or $10 \%$ (Li et al., 2015). The slope and $y$ intercept are $0.95 \pm 0.008$ and $-0.1 \pm 0.01 \mathrm{ppb}$. A larger negative intercept could be related to measurements of higher background for the BLC unit (switch $\mathrm{ON}$ ) leading to underestimation of ambient $\mathrm{NO}_{2}$. An additional background signal is most likely due to decomposition of surface-absorbed $\mathrm{NO}$ or $\mathrm{NO}_{2}$ during the operational mode of the BLC unit (Teflon block).

GANDALF: The sampling flow rate $(12000 \mathrm{sccm})$ provided a residence time of less than $0.1 \mathrm{~s}$ in a $0.5 \mathrm{~m}$ sampling line. This was sufficient to suppress the impact of heterogeneous or thermal conversion of $\mathrm{NO}_{2}$ containing species to yield $\mathrm{NO}_{2}$. The formation of $\mathrm{NO}_{2}$ due to the reaction between ambient $\mathrm{NO}$ and $\mathrm{O}_{3}$ in the sampling line was negligible. The campaign averages of the observed concentrations of $\mathrm{NO}, \mathrm{O}_{3}$, and $\mathrm{NO}_{2}$ were $0.25,44$, and $2.6 \mathrm{ppb}$, respectively. Based on average $\mathrm{NO}$ and $\mathrm{O}_{3}$ concentrations, the formation of $\mathrm{NO}_{2}$ from the reaction $\mathrm{NO}+\mathrm{O}_{3}$ in the sampling line was less than $0.01 \%$ with respect to the ambient $\mathrm{NO}_{2}$ concentrations. Line loss or photolysis of $\mathrm{NO}_{2}$ was avoided by using PTFE lines (polytetrafluoroethylene) covered with a dark insulating material. The average pressure inside the detection cell for the entire period of PARADE was $6.95 \pm 0.27(1 \sigma) \mathrm{hPa}$. Several automated calibrations (2-8 per day) and background level measurements (once per hour) were conducted during PARADE to ensure the precision and accuracy of the instrument. Based on the hourly background level measurements, we established that the deviations for about $70 \%(1 \sigma)$ of successive background signal measurements (number of measurements $>500$ ) were within an equivalent value of \pm 8 ppt of $\mathrm{NO}_{2}$. Any $\mathrm{NO}_{2}$ impurity in the used zero air (Synthetische Luft, KW frei 12er MBdl, Westfalen AG, Germany) (synthetic air hydrocarbon free, without subsequent scrubbing) would lead to an underestimation of ambient $\mathrm{NO}_{2}$ levels for PARADE and further contribute to the uncertainty. Nevertheless, previously described deviations of $8 \mathrm{ppt}$ in the background signal during PARADE could be a good indicator of this uncertainty. Another indication that the $\mathrm{NO}_{2}$ contamination in zero air used during PARADE 2011 was less than GANDALF's detection limit is that in the data analysis the $y$ intercept of other $\mathrm{NO}_{2}$ in situ instruments
( $y$ axis) vs. GANDALF ( $x$ axis) always showed a negative number. If the GANDALF zero measurements had significant $\mathrm{NO}_{2}$ contamination the $y$ intercept should be positive (this figure is provided in the Supplement). A malfunction of the $\mathrm{O}_{3}$ generator occurred in the period 4 to 10 September that disturbed the GANDALF calibration system. A correction of $12 \%$ is introduced for the period 4-10 September, based on the correlation of GANDALF with the CRDS instrument prior to 4 September. During the last few days of this period, an extra baffle was installed in GANDALF. The baffle can be inserted easily into the detection block of GANDALF without disturbing the alignment of the laser. The advantage of the baffle is that it reduces the background counts by $\sim 50 \%$ while decreasing sensitivity by less than $5 \%$. The overall correlation between GANDALF and the derived median $\mathrm{NO}_{2}$ is $R^{2}=0.99$ as shown in Fig. 10b. The measurements of GANDALF tend to be $3 \%$ higher compared to the derived median values of $\mathrm{NO}_{2}$. This overestimation of the slope from unity compared to the derived median value is within the range of the instrument uncertainties. The overall relative uncertainty in GANDALF during PARADE was about $5 \%+11 \mathrm{ppt}$ and it showed an exponentially increasing trend from a higher to lower concentration of $\mathrm{NO}_{2}$. This increasing trend is mainly driven by the error in the background measurements. The slope and $y$ intercept of the fit are 1.03 and $0.027 \mathrm{ppb}$ with the absolute errors of the fit being 0.006 and $0.01 \mathrm{ppb}$.

Generally, all instruments for $\mathrm{NO}_{2}$ showed reasonable agreement with the derived median $\mathrm{NO}_{2}$. Based on Fig. 10, GANDALF $(+3 \%)$, CRDS $(+6 \%)$, and LP-DOAS $(+2 \%)$ showed overestimations compared to the derived median values, while the data were about $-5 \%$ from CLD and about $-8 \%$ lower than the median values from CE-DOAS. The overall differences are within the experimental limitations and instrumental uncertainties. Results of the comparison between individual $\mathrm{NO}_{2}$ measurements and the derived median $\mathrm{NO}_{2}$ at different ranges of $\mathrm{NO}_{2}$ mixing ratios are summarized in Table 3.

\subsection{Ratio distribution of $\mathrm{NO}_{2}$ measurements}

Various measurements of trace gases, meteorological parameters, and photolysis frequencies during PARADE provided an opportunity to look for indications of systematic differences between $\mathrm{NO}_{2}$ instruments. Ratios of the individual $\mathrm{NO}_{2}$ measurements to GANDALF, which are referred to as "ratios" further on in this section, are compared with respect to different atmospheric conditions. The distribution of ratios is shown as a histogram in the upper panel of Fig. 11 (A1, A2, A3, and A4) along their respective fits based on the normal distribution. The normal probability plot for empirical probability vs. ratios is shown in the lower panels (B1, B2, B3, and B4) of Fig. 11. This plot is a graphical representation 

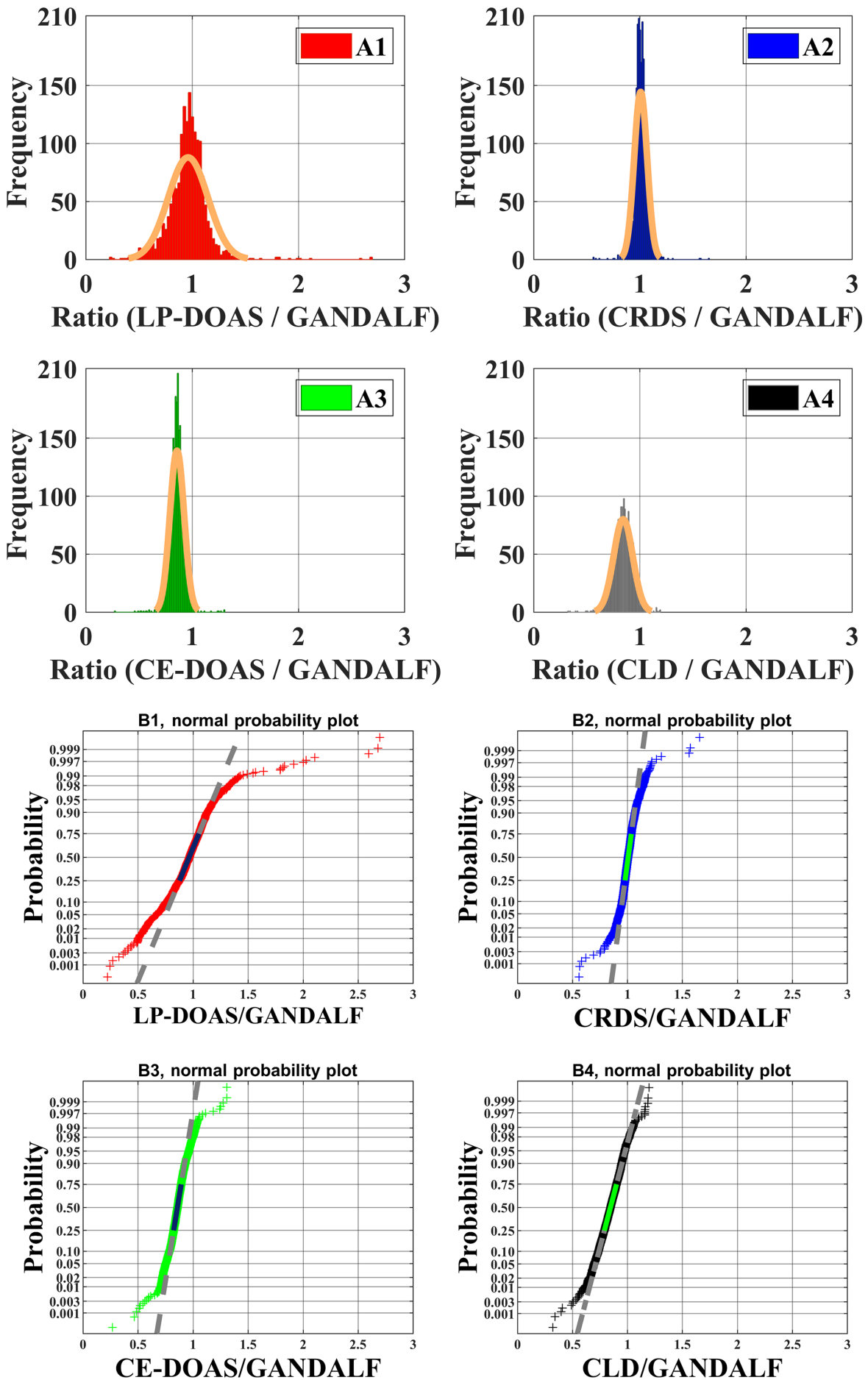

Figure 11. Distribution of comparative instrument ratios of $\mathrm{NO}_{2}$ measurements from different instruments is shown in upper panels (A1 to A4) and a normal probability plot for comparative instrument ratios is shown in lower panels (B1 to B4).

of the normal distribution of ratios. The plot stays linear as long as the distributions are normal, and the deviation from the linear fit shows the divergence from the normal distribution. The solid line in the lower panels of Fig. 11 is in the 25th and 75th interquartile range of a ratio. The probability's grid ( $y$ grid lines) is not linear and it is representative of the distance between quantiles of normal distribution.

The average, median, and standard deviations of ratios comparing GANDALF with other instruments are given in Table 4. The variation in these ratios (CRDS/GANDALF, 
Table 4. Average values of $\mathrm{NO}_{2}$ ratios during PARADE 2011. These are derived from the different overall $\mathrm{NO}_{2}$ measurements with respect to GANDALF overall $\mathrm{NO}_{2}$ measurement.

\begin{tabular}{lrr}
\hline Ratio & Average & $\begin{array}{r}\text { Standard } \\
\text { deviation }\end{array}$ \\
\hline LP-DOAS/GANDALF & 0.96 & 0.19 \\
CRDS/GANDALF & 1.01 & 0.06 \\
CE-DOAS/GANDALF & 0.86 & 0.07 \\
CLD/GANDALF & 0.85 & 0.09 \\
\hline
\end{tabular}
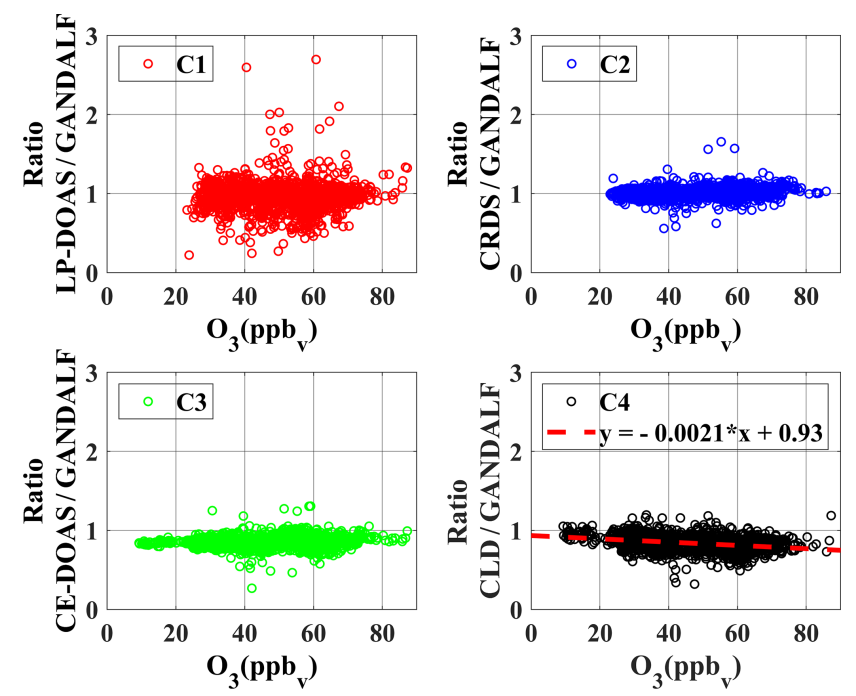

Figure 12. Ratios as a function of ambient $\mathrm{O}_{3}$ during PARADE.

CE-DOAS/GANDALF, and CLD/GANDALF) is small compared to LP-DOAS/GANDALF. This is expected as the LP-DOAS is not an in situ technique and instead measures an average concentration along the light path. The ratios CRDS/GANDALF and LP-DOAS/GANDALF are close to unity, whereas in the case of CE-DOAS/GANDALF and CLD/GANDALF they deviate from unity by 0.15 . All ratio distributions generally show a trend close to a normal distribution (Fig. 11, A1, A2, A3, and A4) but the skewness in LP-DOAS/GANDALF (A1 in Fig. 11) on both sides of the average value is relatively large. In the lower panel of Fig. 11 (B1, B2, B3, and B4), the probabilities show a deviation from the norm and a tail on the top (towards the right) and bottom (towards the left) sides can be observed. The tail could be an indicator of outliers, for example caused by the non-normality of the precision at low values, background level, and potential interferences of $\mathrm{NO}_{2}$ instruments. The lower panels (B1, B2, B3, and B4) of Fig. 11 show that a major fraction of the ratios is normally distributed, evident from the 25th to 75th interquartile range of probability in all cases. The percentile of probability towards normality is slightly greater (about 10th to 90th percentile) in the case of CLD/GANDALF compared to the others. The percentile is
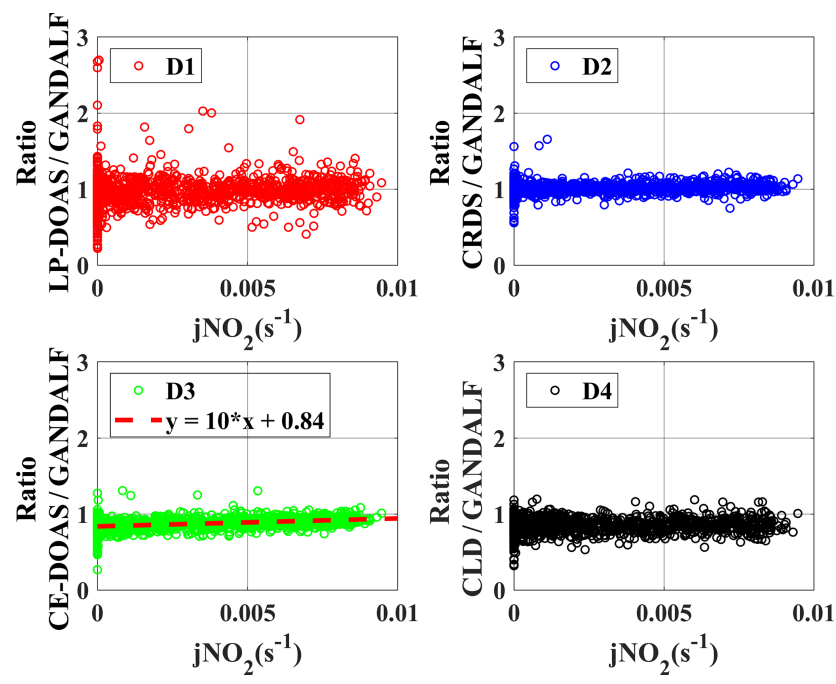

Figure 13. Ratios as a function of measured $j \mathrm{NO}_{2}$ during PARADE.

about 15th to 80th and 25th to 90th with CRD/GANDALF, CE-DOAS/GANDALF and LP-DOAS/GANDALF. A perfect normal distribution should not be expected in these cases as, mathematically, a ratio between two normally distributed quantities does not follow a normal distribution, but it can be a distribution like the Cauchy distribution (Weisstein, 2003). The long tails in the lower panel of Fig. 11 (B1, B2, B3, and B4) also indicates the characteristics of the Cauchy distribution. In this type of distribution, the accuracy of average and standard deviation values cannot be increased by increasing the number of data points.

To identify systematic deviations based on other trace gases or parameters, ratios are further compared with the observed data of several trace gases, radiation, and meteorological parameters. There are only two cases in which a systematic correlation of ratios was observed with the observed quantities during PARADE, as shown in Figs. 12 and 13. In Case 1, ratios are presented as a function of the observed $\mathrm{O}_{3}$ concentrations. The ratio between CLD and GANDALF shows a decreasing trend with respect to an increase in the $\mathrm{O}_{3}$ concentrations (panel C4, Fig. 12). This ratio (CLD/GANDALF) averages 0.95 at levels less than $20 \mathrm{ppb} \mathrm{O}_{3}$. It decreases to an average of 0.86 over the interval of 20 to $42 \mathrm{ppb} \mathrm{O}_{3}$, while averaging 0.81 at levels above $42 \mathrm{ppb}$ of $\mathrm{O}_{3}$. There is no trend observed in other ratios (CRDS/GANDALF, LP-DOAS/GANDALF, and CE-DOAS/GANDALF) as shown in Fig. 12. The subplot (C4, Fig. 12) has been cross-checked by altering the GANDALF data in the denominator to the other three measurements (LP-DOAS, CRDS, and CE-DOAS) and qualitatively similar trends were observed as with GANDALF. The reason for this CLD/GANDALF trend is not clear at the moment. However, it seems that this trend may be an indirect impact due to the zero-air measurement of the CLD with 
the BLC unit ON, which is dependent on the converter's history (exposition to ambient $\mathrm{NO}, \mathrm{NO}_{2}$, and $\mathrm{HNO}_{3}$ concentrations along humidity) and potentially affects the ambient $\mathrm{NO}_{2}$ measurements. Therefore, the dependency on $\mathrm{O}_{3}$ might be an indirect effect: high ozone could point to transport from above with lower $\mathrm{H}_{2} \mathrm{O}$ and lower $\mathrm{NO}_{x}$, which could affect the zero, leading to an overestimation of the subtracted zero signal. In Case 2 (subplot D3, Fig. 13), a correlation is observed for the ratio between CE-DOAS/GANDALF as a function of $j \mathrm{NO}_{2}$. At higher values of $j \mathrm{NO}_{2}$, the ratio approaches unity. The sampling line for CE-DOAS and CRDS was the same and no correlation for the ratio between CRDS and GANDALF is seen with respect to $j \mathrm{NO}_{2}$. However, the data for the CRDS instrument were corrected for the effect of $\mathrm{NO}+\mathrm{O}_{3} \rightarrow \mathrm{NO}_{2}$ in the sampling line and this correction for the CE-DOAS instrument was not implemented. Hence, the $j \mathrm{NO}_{2}$ trend in the ratio could be indirectly from $\mathrm{NO}+\mathrm{O}_{3}$. A residence time of $10 \mathrm{~s}$ in the sampling line for the $\mathrm{NO}+\mathrm{O}_{3} \rightarrow \mathrm{NO}_{2}$ reaction (using measured $\mathrm{NO}$, and $\mathrm{O}_{3}$ ) is sufficient to explain this trend. This correlation is also not observed for the ratios of LP-DOAS and CLD with respect to GANDALF. A cross-check was done for panel D3 (Fig. 13) by exchanging GANDALF in the denominator to three other measurements (LP-DOAS, CRDS, and CLD); qualitatively similar trends were observed as previously. Besides the above-described systematic correlations, no indication of a potential interference is obtained for any of the instruments.

\section{Summary}

The laser-induced fluorescence-based instrument (GANDALF) has been developed for the measurement of atmospheric $\mathrm{NO}_{2}$. GANDALF has been tailored towards a compact design with a low detection limit $\left(5-10 \mathrm{ppt} \mathrm{min}^{-1}\right)$ and high precision $\left(0.5 \%+3 \mathrm{ppt} \mathrm{min}^{-1}\right)$, making it capable of measuring $\mathrm{NO}_{2}$ throughout the troposphere with a time resolution of $1 \mathrm{~min}$. The reliability of GANDALF was successfully tested during the PARADE 2011 field campaign. Several available $\mathrm{NO}_{2}$ measurements based on different methods (absorption spectroscopy, chemiluminescence, and fluorescence) provided a unique chance of successful intercomparison. In general, all instruments performed well. GANDALF showed a very good correlation $\left(R^{2} \approx 0.99\right)$ in comparison to other in situ instruments (Fig. S11 in the Supplement), and even with LP-DOAS the correlation was $R^{2} \approx 0.9$. The differences in the absolute values were within the specified range of individual measurement errors. The main advantages and disadvantages of GANDALF compared to the other instruments are summarized as follows.

In comparison to the CRDS instrument, the main advantage for GANDALF is that the sampling can be achieved without an inlet line. This is not possible for the closed-path CRDS system. This provides the capability of the detection at ambient temperature for GANDALF, which is especially an advantage for aircraft measurements of $\mathrm{NO}_{2}$, where avoiding interference from $\mathrm{CH}_{3} \mathrm{OONO}_{2}$ and $\mathrm{HO}_{2} \mathrm{NO}_{2}$ (via unwanted thermal dissociation) is very important. The requirement of calibration is the main disadvantage of GANDALF compared to CRDS (absolute technique). However, both instruments require frequent zero-air measurements. The limits of detection for the instruments were of similar magnitude during PARADE 2011.

The CE-DOAS instrument is comparable to the CRDS instrument. It also needs frequent background measurements but no absolute calibration. GANDALF has a much better sensitivity compared to the CE-DOAS instrument. During PARADE 2011, the detection limit for CE-DOAS was around $300 \mathrm{ppt}(2 \sigma, 30 \mathrm{~s})$, while for GANDALF the detection limit was 5-10 ppt $\left(\mathrm{min}^{-1}\right)$. A low cell pressure is typically required to achieve good sensitivity for LIF instruments (Table 1), while the detection in the other instruments (CRDS and CE-DOAS) is performed at sub-ambient pressures $(>800 \mathrm{hPa})$. The requirement of calibration and usage of a larger scroll-pump (to achieve a low-cell-pressure) adds extra effort and cost to the GANDALF measurements.

The basic requirements for a calibration and background measurements are the same in CLD and GANDALF. In the case of CLD, the maintenance is relatively easy compared to GANDALF. However, GANDALF provides a direct detection of $\mathrm{NO}_{2}$ compared to the indirect detection of $\mathrm{NO}_{2}$ (via $\mathrm{NO}_{2} \rightarrow \mathrm{NO}$ ) in the CLD instrument. The sensitivity of GANDALF was better than the CLD instrument during PARADE 2011.

LP-DOAS does not require calibration or the zero-air measurement. For this reason, the uncertainty in the data is also very small compared to GANDALF or other in situ measurements. This is the main advantage of the LP-DOAS instrument over GANDALF. The restriction of this method is that it does not provide a local measurement. Also, the temporal resolution is limited compared to other in situ instruments. The sensitivity of the LP-DOAS instrument generally depends on the length of a light path and variations in visibility. It was on average about $110 \mathrm{ppt}(2 \sigma, 11 \mathrm{~s})$ during PARADE 2011.

The selectivity of the $\mathrm{NO}_{2}$ measurement with GANDALF compared to other measurements in ambient air was assessed during PARADE and no potential interference was found. This prototype could provide useful measurements of $\mathrm{NO}_{2}$ under remote conditions where an interference-free detection is absolutely essential for the study of $\mathrm{NO}_{x}$ chemistry, especially in the context of $\mathrm{O}_{3}$ formation, and radical loss processes.

\section{Outlook}

$\mathrm{NO}_{2}$ in the free troposphere is variable (seasonally) and generally lower than 50 ppt (Gil-Ojeda et al., 2015). Depending 
on the location, in the free troposphere and the marine boundary layer, $\mathrm{NO}_{2}$ can be as low as a few ppt (Hosaynali Beygi et al., 2011; Schreier et al., 2016). These $\mathrm{NO}_{2}$ ranges are below the detection limit for the instrument (GANDALF) for short time resolutions of $1 \mathrm{~s}$, for example. Improvements for future use on the aircraft are possible by further reducing the background of the instrument. Since most of the background signal is from the fluorescence contamination of the Herriot's cell mirrors, this could be avoided by using a single beam (as demonstrated by Di Carlo et al., 2013) of the laser for detection without a Herriott cell or by using different coatings on the Herriott cell mirrors to increase reflectivity and reduce fluorescence. The current $\mathrm{CW}$ diode laser of the instrument may be replaced by an already available monomode dualdiode laser $[\lambda($ online $)=445 \mathrm{~nm}$ and $\lambda($ offline $)=442 \mathrm{~nm}$ ] for on and off resonance measurements of $\mathrm{NO}_{2}$. Replacement of the current laser by a dual-diode laser will partially decrease the dependency on the frequent zero-air background measurements.

The formation of $\mathrm{RONO}_{2}$ is an important sink for $\mathrm{NO}_{x}$ and affects the ozone production efficiency (Browne and Cohen, 2012). The accurate measurement of $\mathrm{RONO}_{2}$ is important for the assessment of local $\mathrm{O}_{3}$ abundances. LIF systems in combination with the thermal dissociation method (Day et al., 2002) are also used and are very useful for the detection of $\mathrm{RONO}_{2}, \mathrm{RONO}_{2}$, and $\mathrm{HNO}_{3}$. GANDALF will be capable (currently under development) of measuring these species by coupling them with the thermal dissociation inlets. This further development could provide very useful data in the future to constrain models.

Data availability. Details about the field campaign can be found at http://parade2011.mpich.de/ (last access: 28 February 2019). The data related to PARADE 2011 can be obtained on request (by Hartwig Harder) from the responsible persons/owners.

Supplement. The supplement related to this article is available online at: https://doi.org/10.5194/amt-12-1461-2019-supplement.

Competing interests. The authors declare that they have no conflict of interest.

Acknowledgements. This work was done as a part of the first author's $\mathrm{PhD}$, who is grateful for the constructive comments of Peter Hoor during the $\mathrm{PhD}$ advisory committee meetings. The financial support from DFG (Deutsche Forschungsgemeinschaft) within the "DFG-Verfahren: Schwerpunktprogramm, SPP 1294: Bereich Infrastruktur - Atmospheric and Earth system research with the 'High Altitude and Long Range Research Aircraft' (HALO)" is gratefully acknowledged. The authors are thankful to Mingjin Tang, Birger Bohn, Florian Berkes, and Gavin J. Phillips for the data on $\mathrm{NO}_{3} / \mathrm{N}_{2} \mathrm{O}_{5}, j \mathrm{NO}_{2}, \mathrm{H}_{2} \mathrm{O}$, and $\mathrm{ClNO}_{2}$, respectively.
The acknowledgement extends to Korbinian Hens, Anna Novelli, Eric Regelin, Cheryl T. Ernest, and Chinmay Mallik for their useful comments/logistics, the site engineers, DWD (Germany's National Meteorological Service) for meteorological data, and to the Goethe University, Frankfurt, for use of the Taunus Observatory facilities. We are thankful to the three anonymous referees for their comments and suggestions that helped us to improve the draft. We are also thankful to Lisa Whalley (editor) for the review process.

The article processing charges for this open-access publication were covered by a Research Centre of the Helmholtz Association.

Edited by: Lisa Whalley

Reviewed by: three anonymous referees

\section{References}

Atkinson, R., Baulch, D. L., Cox, R. A., Crowley, J. N., Hampson, R. F., Hynes, R. G., Jenkin, M. E., Rossi, M. J., and Troe, J.: Evaluated kinetic and photochemical data for atmospheric chemistry: Volume $\mathrm{I}-$ gas phase reactions of $\mathrm{O}_{x}, \mathrm{HO}_{x}$, $\mathrm{NO}_{x}$ and $\mathrm{SO}_{x}$ species, Atmos. Chem. Phys., 4, 1461-1738, https://doi.org/10.5194/acp-4-1461-2004, 2004.

Bekooy, J. P., Meerts, W. L., and Dymanus, A.: HighResolution Laser-rf Spectroscopy on the $A^{2} \Pi_{3 / 2}-X^{2} \Pi_{3 / 2}$ System of Iodine Oxide (IO), J. Mol. Spectrosc., 102, 320-343, https://doi.org/10.1016/0022-2852(83)90044-9, 1983.

Bonn, B., Bourtsoukidis, E., Sun, T. S., Bingemer, H., Rondo, L., Javed, U., Li, J., Axinte, R., Li, X., Brauers, T., Sonderfeld, H., Koppmann, R., Sogachev, A., Jacobi, S., and Spracklen, D. V.: The link between atmospheric radicals and newly formed particles at a spruce forest site in Germany, Atmos. Chem. Phys., 14, 10823-10843, https://doi.org/10.5194/acp-14-108232014, 2014.

Bradshaw, J., Davis, D., Crawford, J., Chen, G., Shetter, R., Muller, M., Gregory, G., Sachse, G., Blake, D., Heikes, B., Singh, H., Mastromarino, J., and Sandholm, S.: Photofragmentation twophoton laser-induced fluorescence detection of $\mathrm{NO}_{2}$ and $\mathrm{NO}$ : Comparison of measurements with model results based on airborne observations during PEM-Tropics A, Geophys. Res. Lett., 26, 471-474, https://doi.org/10.1029/1999g1900015, 1999.

Browne, E. C. and Cohen, R. C.: Effects of biogenic nitrate chemistry on the $\mathrm{NO}_{x}$ lifetime in remote continental regions, Atmos. Chem. Phys., 12, 11917-11932, https://doi.org/10.5194/acp-1211917-2012, 2012.

Burkholder, J. B., Talukdar, R. K., Ravishankara, A. R., and Solomon, S.: Temperature-Dependence of the $\mathrm{HNO}_{3}$ UV Absorption Cross-Sections, J. Geophys. Res.-Atmos., 98, 2293722948, https://doi.org/10.1029/93jd02178, 1993.

Butkovskaya, N., Kukui, A., and Le Bras, G.: $\mathrm{HNO}_{3}$ forming channel of the $\mathrm{HO}_{2}+\mathrm{NO}$ reaction as a function of pressure and temperature in the ranges of 72-600 torr and 223-323 K, J. Phys. Chem. A, 111, 9047-9053, https://doi.org/10.1021/jp074117m, 2007.

Cantrell, C. A.: Technical Note: Review of methods for linear least-squares fitting of data and application to atmo- 
spheric chemistry problems, Atmos. Chem. Phys., 8, 5477-5487, https://doi.org/10.5194/acp-8-5477-2008, 2008.

Cariolle, D., Evans, M. J., Chipperfield, M. P., Butkovskaya, N., Kukui, A., and Le Bras, G.: Impact of the new $\mathrm{HNO}_{3}$-forming channel of the $\mathrm{HO}_{2}+\mathrm{NO}$ reaction on tropospheric $\mathrm{HNO}_{3}$, $\mathrm{NO}_{x}, \mathrm{HO}_{x}$ and ozone, Atmos. Chem. Phys., 8, 4061-4068, https://doi.org/10.5194/acp-8-4061-2008, 2008.

Carpenter, L. J., Monks, P. S., Bandy, B. J., Penkett, S. A., Galbally, I. E., and Meyer, C. P.: A study of peroxy radicals and ozone photochemistry at coastal sites in the northern and southern hemispheres, J. Geophys. Res.-Atmos., 102, 25417-25427, https://doi.org/10.1029/97jd02242, 1997.

Clapp, L. J. and Jenkin, M. E.: Analysis of the relationship between ambient levels of $\mathrm{O}_{3}, \mathrm{NO}_{2}$ and $\mathrm{NO}$ as a function of NO chi in the UK, Atmos. Environ., 35, 6391-6405, https://doi.org/10.1016/S1352-2310(01)00378-8, 2001.

Cleary, P. A., Wooldridge, P. J., and Cohen, R. C.: Laser-induced fluorescence detection of atmospheric $\mathrm{NO}_{2}$ with a commercial diode laser and a supersonic expansion, Appl. Optics, 41, 69506956, https://doi.org/10.1364/Ao.41.006950, 2002.

Commane, R., Seitz, K., Bale, C. S. E., Bloss, W. J., Buxmann, J., Ingham, T., Platt, U., Pöhler, D., and Heard, D. E.: Iodine monoxide at a clean marine coastal site: observations of high frequency variations and inhomogeneous distributions, Atmos. Chem. Phys., 11, 6721-6733, https://doi.org/10.5194/acp11-6721-2011, 2011.

Crawford, J., Davis, D., Chen, G., Bradshaw, J., Sandholm, S., Gregory, G., Sachse, G., Anderson, B., Collins, J., Blake, D., Singh, H., Heikes, B., Talbot, R., and Rodriguez, J.: Photostationary state analysis of the $\mathrm{NO}_{2}-\mathrm{NO}$ system based on airborne observations from the western and central North Pacific, J. Geophys. Res.-Atmos., 101, 2053-2072, https://doi.org/10.1029/95jd02201, 1996.

Crutzen, P. J.: Role of $\mathrm{NO}$ and $\mathrm{NO}_{2}$ in the Chemistry of the Troposphere and Stratosphere, Annu. Rev. Earth Pl. Sc., 7, 443-472, https://doi.org/10.1146/annurev.ea.07.050179.002303, 1979.

Dari-Salisburgo, C., Di Carlo, P., Giammaria, F., Kajii, Y., and D'Altorio, A.: Laser induced fluorescence instrument for $\mathrm{NO}_{2}$ measurements: Observations at a central Italy background site, Atmos. Environ., 43, 970-977, https://doi.org/10.1016/j.atmosenv.2008.10.037, 2009.

Day, D. A., Wooldridge, P. J., Dillon, M. B., Thornton, J. A., and Cohen, R. C.: A thermal dissociation laser-induced fluorescence instrument for in situ detection of $\mathrm{NO}_{2}$, peroxy nitrates, alkyl nitrates, and $\mathrm{HNO}_{3}$, J. Geophys. Res.-Atmos., 107, 4046, https://doi.org/10.1029/2001jd000779, 2002.

Di Carlo, P., Aruffo, E., Busilacchio, M., Giammaria, F., DariSalisburgo, C., Biancofiore, F., Visconti, G., Lee, J., Moller, S., Reeves, C. E., Bauguitte, S., Forster, G., Jones, R. L., and Ouyang, B.: Aircraft based four-channel thermal dissociation laser induced fluorescence instrument for simultaneous measurements of $\mathrm{NO}_{2}$, total peroxy nitrate, total alkyl nitrate, and $\mathrm{HNO}_{3}$, Atmos. Meas. Tech., 6, 971-980, https://doi.org/10.5194/amt-6971-2013, 2013.

Ehhalt, D. H., Rohrer, F., and Wahner, A.: Sources and distribution of $\mathrm{NO}_{x}$ in the upper troposphere at northern midlatitudes, J. Geophys. Res., 97, 3725-3738, https://doi.org/10.1029/91JD03081, 1992..
Fong, C. and Brune, W. H.: A laser induced fluorescence instrument for measuring tropospheric $\mathrm{NO}_{2}$, Rev. Sci. Instrum., 68, 4253, https://doi.org/10.1063/1.1148384, 1997.

Fontijn, A., Sabadell, A. J., and Ronco, R. J.: Homogeneous Chemiluminescent Measurement of Nitric Oxide with Ozone - Implications for Continuous Selective Monitoring of Gaseous Air Pollutants, Anal. Chem., 42, 575-579, https://doi.org/10.1021/Ac60288a034, 1970.

Ge, B. Z., Sun, Y. L., Liu, Y., Dong, H. B., Ji, D. S., Jiang, Q., Li, J., and Wang, Z. F.: Nitrogen dioxide measurement by cavity attenuated phase shift spectroscopy (CAPS) and implications in ozone production efficiency and nitrate formation in Beijing, China, J. Geophys. Res.-Atmos., 118, 9499-9509, https://doi.org/10.1002/Jgrd.50757, 2013.

George, L. A. and Obrien, R. J.: Prototype Fage Determination of $\mathrm{NO}_{2}$, J. Atmos. Chem., 12, 195-209, https://doi.org/10.1007/Bf00048073, 1991.

Ghosh, B., Papanastasiou, D. K., Talukdar, R. K., Roberts, J. M., and Burkholder, J. B.: Nitryl Chloride $\left(\mathrm{CINO}_{2}\right)$ : UV/Vis Absorption Spectrum between 210 and $296 \mathrm{~K}$ and O(P-3) Quantum Yield at 193 and $248 \mathrm{~nm}$, J. Phys. Chem. A, 116, 5796-5805, https://doi.org/10.1021/Jp207389y, 2012.

Gil-Ojeda, M., Navarro-Comas, M., Gómez-Martín, L., Adame, J. A., Saiz-Lopez, A., Cuevas, C. A., González, Y., Puentedura, O., Cuevas, E., Lamarque, J.-F., Kinninson, D., and Tilmes, S.: $\mathrm{NO}_{2}$ seasonal evolution in the north subtropical free troposphere, Atmos. Chem. Phys., 15, 10567-10579, https://doi.org/10.5194/acp-15-10567-2015, 2015.

Gottschaldt, K., Voigt, C., Jöckel, P., Righi, M., Deckert, R., and Dietmüller, S.: Global sensitivity of aviation $\mathrm{NO}_{x}$ effects to the $\mathrm{HNO}_{3}$-forming channel of the $\mathrm{HO}_{2}+\mathrm{NO}$ reaction, Atmos. Chem. Phys., 13, 3003-3025, https://doi.org/10.5194/acp-133003-2013, 2013.

Harwood, M. H., Jones, R. L., Cox, R. A., Lutman, E., and Rattigan, O. V.: Temperature-Dependent Absorption CrossSections of $\mathrm{N}_{2} \mathrm{O}_{5}$, J. Photoch. Photobio. A, 73, 167-175, https://doi.org/10.1016/1010-6030(93)90001-2, 1993.

Harwood, M. H., Burkholder, J. B., Hunter, M., Fox, R. W., and Ravishankara, A. R.: Absorption cross sections and self-reaction kinetics of the IO radical, J. Phys. Chem. A, 101, 853-863, https://doi.org/10.1021/Jp962429b, 1997.

Herndon, S. C., Shorter, J. H., Zahniser, M. S., Nelson, D. D., Jayne, J., Brown, R. C., Miake-Lye, R. C., Waitz, I., Silva, P., Lanni, T., Demerjian, K., and Kolb, C. E.: NO and $\mathrm{NO}_{2}$ emission ratios measured from in-use commercial aircraft during taxi and takeoff, Environ. Sci. Technol., 38, 6078-6084, https://doi.org/10.1021/Es049701c, 2004.

Herriott, D., Kompfner, R., and Kogelnik, H.: Off-Axis Paths in Spherical Mirror Interferometers, Appl. Optics, 3, 523, https://doi.org/10.1364/Ao.3.000523, 1964.

Hofzumahaus, A., Rohrer, F., Lu, K. D., Bohn, B., Brauers, T., Chang, C. C., Fuchs, H., Holland, F., Kita, K., Kondo, Y., Li, X., Lou, S. R., Shao, M., Zeng, L. M., Wahner, A., and Zhang, Y. H.: Amplified Trace Gas Removal in the Troposphere, Science, 324, 1702-1704, https://doi.org/10.1126/science.1164566, 2009.

Horowitz, A., Meller, R., and Moortgat, G. K.: The UV-VIS absorption cross sections of the alpha-dicarbonyl compounds: Pyruvic acid, biacetyl and glyoxal, J. Photoch. Photobio. A, 146, 19-27, https://doi.org/10.1016/S1010-6030(01)00601-3, 2001. 
Hosaynali Beygi, Z., Fischer, H., Harder, H. D., Martinez, M., Sander, R., Williams, J., Brookes, D. M., Monks, P. S., and Lelieveld, J.: Oxidation photochemistry in the Southern Atlantic boundary layer: unexpected deviations of photochemical steady state, Atmos. Chem. Phys., 11, 8497-8513, https://doi.org/10.5194/acp-11-8497-2011, 2011.

Keller-Rudek, H., Moortgat, G. K., Sander, R., and Sörensen, R.: The MPI-Mainz UV / VIS Spectral Atlas of Gaseous Molecules of Atmospheric Interest, Earth Syst. Sci. Data, 5, 365-373, https://doi.org/10.5194/essd-5-365-2013, 2013.

Kubistin, D., Harder, H., Martinez, M., Rudolf, M., Sander, R., Bozem, H., Eerdekens, G., Fischer, H., Gurk, C., Klüpfel, T., Königstedt, R., Parchatka, U., Schiller, C. L., Stickler, A., Taraborrelli, D., Williams, J., and Lelieveld, J.: Hydroxyl radicals in the tropical troposphere over the Suriname rainforest: comparison of measurements with the box model MECCA, Atmos. Chem. Phys., 10, 9705-9728, https://doi.org/10.5194/acp10-9705-2010, 2010.

Land, D. V., Levick, A. P., and Hand, J. W.: The use of the Allan deviation for the measurement of the noise and drift performance of microwave radiometers, Meas. Sci. Technol., 18, 1917-1928, https://doi.org/10.1088/0957-0233/18/7/018, 2007.

Lelieveld, J. and Crutzen, P. J.: Influences of Cloud Photochemical Processes on Tropospheric Ozone, Nature, 343, 227-233, https://doi.org/10.1038/343227a0, 1990.

Lelieveld, J., Butler, T. M., Crowley, J. N., Dillon, T. J., Fischer, H., Ganzeveld, L., Harder, H., Lawrence, M. G., Martinez, M., Taraborrelli, D., and Williams, J.: Atmospheric oxidation capacity sustained by a tropical forest, Nature, 452, 737-740, https://doi.org/10.1038/nature06870, 2008.

Li, J. S., Reiffs, A., Parchatka, U., and Fischer, H.: In Situ Measurements of Atmospheric Co and Its Correlation with $\mathrm{NO}_{x}$ and $\mathrm{O}_{3}$ at a Rural Mountain Site, Metrol. Meas. Syst., 22, 25-38, 2015.

Logan, J. A.: Nitrogen-Oxides in the Troposphere - Global and Regional Budgets, J. Geophys. Res.-Oc. Atm., 88, 785-807, https://doi.org/10.1029/Jc088ic15p10785, 1983.

Martinez, M., Harder, H., Kubistin, D., Rudolf, M., Bozem, H., Eerdekens, G., Fischer, H., Klüpfel, T., Gurk, C., Königstedt, R., Parchatka, U., Schiller, C. L., Stickler, A., Williams, J., and Lelieveld, J.: Hydroxyl radicals in the tropical troposphere over the Suriname rainforest: airborne measurements, Atmos. Chem. Phys., 10, 3759-3773, https://doi.org/10.5194/acp10-3759-2010, 2010.

Matsumi, Y., Murakami, S., Kono, M., Takahashi, K., Koike, M., and Kondo, Y.: High-sensitivity instrument for measuring atmospheric $\mathrm{NO}_{2}$, Anal. Chem., 73, 5485-5493, https://doi.org/10.1021/Ac010552f, 2001.

Matsumoto, J. and Kajii, Y.: Improved analyzer for nitrogen dioxide by laser-induced fluorescence technique, Atmos. Environ., 37, 4847-4851, https://doi.org/10.1016/j.atmosenv.2003.08.023, 2003.

Matsumoto, J., Hirokawa, J., Akimoto, H., and Kajii, Y.: Direct measurement of $\mathrm{NO}_{2}$ in the marine atmosphere by laserinduced fluorescence technique, Atmos. Environ., 35, 2803 2814, https://doi.org/10.1016/S1352-2310(01)00078-4, 2001.

Meller, R., Raber, W., Crowley, J. N., Jenkin, M. E., and Moortgat, G. K.: The Uv-Visible Absorption-Spectrum of Methylglyoxal, J. Photoch. Photobio. A, 62, 163-171, https://doi.org/10.1016/1010-6030(91)87017-P, 1991.
Molina, L. T. and Molina, M. J.: Ultraviolet-Absorption Spectrum of Chlorine Nitrite, Clono, Geophys. Res. Lett., 4, 83-86, https://doi.org/10.1029/G1004i002p00083, 1977.

Molina, L. T. and Molina, M. J.: Chlorine Nitrate UltravioletAbsorption Spectrum at Stratospheric Temperatures, J. Photochem., 11, 139-144, https://doi.org/10.1016/00472670(79)80047-7, 1979.

Mollner, A. K., Valluvadasan, S., Feng, L., Sprague, M. K., Okumura, M., Milligan, D. B., Bloss, W. J., Sander, S. P., Martien, P. T., Harley, R. A., McCoy, A. B., and Carter, W. P. L.: Rate of Gas Phase Association of Hydroxyl Radical and Nitrogen Dioxide, Science, 330, 646-649, https://doi.org/10.1126/science.1193030, 2010.

Monks, P. S.: Gas-phase radical chemistry in the troposphere, Chem. Soc. Rev., 34, 376-395, https://doi.org/10.1039/b307982c, 2005.

Newman, S. M., Howie, W. H., Lane, I. C., Upson, M. R., and OrrEwing, A. J.: Predissociation of the $\mathrm{A}^{2} \Pi_{3 / 2}$ state of IO studied by cavity ring-down spectroscopy, J. Chem. Soc. Faraday. T., 94, 2681-2688, https://doi.org/10.1039/A805103h, 1998.

Osthoff, H. D., Brown, S. S., Ryerson, T. B., Fortin, T. J., Lerner, B. M., Williams, E. J., Pettersson, A., Baynard, T., Dube, W. P., Ciciora, S. J., and Ravishankara, A. R.: Measurement of atmospheric $\mathrm{NO}_{2}$ by pulsed cavity ringdown spectroscopy, J. Geophys. Res.-Atmos., 111, D12305, https://doi.org/10.1029/2005jd006942, 2006.

Parra, J. and George, L. A.: Development of an ambient pressure laser-induced fluorescence instrument for nitrogen dioxide, Appl. Optics, 48, 3355-3361, https://doi.org/10.1364/AO.48.003355, 2009.

Perner, D. and Platt, U.: Detection of Nitrous-Acid in the Atmosphere by Differential Optical-Absorption, Geophys. Res. Lett., 6, 917-920, https://doi.org/10.1029/G1006i012p00917, 1979.

Phillips, G. J., Tang, M. J., Thieser, J., Brickwedde, B., Schuster, G., Bohn, B., Lelieveld, J., and Crowley, J. N.: Significant concentrations of nitryl chloride observed in rural continental Europe associated with the influence of sea salt chloride and anthropogenic emissions, Geophys. Res. Lett., 39, L10811, https://doi.org/10.1029/2012g1051912, 2012.

Platt, U. and Stutz, J.: Differential Optical Absorption Spectroscopy, Springer-Verlag, Berlin Heidelberg, 2008.

Platt, U., Perner, D., and Patz, H. W.: Simultaneous Measurement of Atmospheric $\mathrm{CH}_{2} \mathrm{O}, \mathrm{O}_{3}$, and $\mathrm{NO}_{2}$ by Differential Optical-Absorption, J. Geophys. Res.-Oc. Atm., 84, 6329-6335, https://doi.org/10.1029/Jc084ic10p06329, 1979.

Platt, U., Meinen, J., Pöhler, D., and Leisner, T.: Broadband Cavity Enhanced Differential Optical Absorption Spectroscopy (CEDOAS) - applicability and corrections, Atmos. Meas. Tech., 2, 713-723, https://doi.org/10.5194/amt-2-713-2009, 2009.

Pöhler, D., Vogel, L., Friess, U., and Platt, U.: Observation of halogen species in the Amundsen Gulf, Arctic, by active long-path differential optical absorption spectroscopy, P. Natl. Acad. Sci. USA, 107, 6582-6587, https://doi.org/10.1073/pnas.0912231107, 2010.

Reed, C., Evans, M. J., Di Carlo, P., Lee, J. D., and Carpenter, L. J.: Interferences in photolytic $\mathrm{NO}_{2}$ measurements: explanation for an apparent missing oxidant?, Atmos. Chem. Phys., 16, 47074724, https://doi.org/10.5194/acp-16-4707-2016, 2016. 
Riley, W. J.: A test suite for the calculation of time domain frequency stability, Proceedings of the 1995 Ieee International Frequency Control Symposium, 360-366, https://doi.org/10.1109/Freq.1995.483922, 1995.

Riley, W. J.: Handbook of Frequency Stability Analysis, National Institute of Standards and Technology (NIST), U.S. Department of Commerce, USA, 136 pp., 2008.

Ryerson, T. B., Williams, E. J., and Fehsenfeld, F. C.: An efficient photolysis system for fast-response $\mathrm{NO}_{2}$ measurements, J. Geophys. Res.-Atmos., 105, 26447-26461, https://doi.org/10.1029/2000jd900389, 2000.

Sakurai, K. and Broida, H. P.: Spectral Study of $\mathrm{NO}_{2}$ Fluorescence Excited by 11 Lines of Argon and Krypton Ion Lasers, J. Chem. Phys., 50, 2404, https://doi.org/10.1063/1.1671395, 1969.

Sander, S. P., Abbatt, J., Barker, J. R., Burkholder, J. B., Friedl, R. R., Golden, D. M., Huie, R. E., Kolb, C. E., Kurylo, M. J., Moortgat, G. K., Orkin, V. L., and Wine, P. H.: Chemical Kinetics and Photochemical Data for Use in Atmospheric Studies, JPL Publication, Jet Propulsion Laboratory, Pasadena, 10-6, 2011.

Sandholm, S. T., Bradshaw, J. D., Dorris, K. S., Rodgers, M. O., and Davis, D. D.: An Airborne Compatible Photofragmentation 2-Photon Laser-Induced Fluorescence Instrument for Measuring Background Tropospheric Levels of NO, $\mathrm{NO}_{x}$, and $\mathrm{NO}_{2}$, J. Geophys. Res.-Atmos., 95, 10155-10161, https://doi.org/10.1029/JD095iD07p10155, 1990.

Schreier, S. F., Richter, A., Wittrock, F., and Burrows, J. P.: Estimates of free-tropospheric $\mathrm{NO}_{2}$ and $\mathrm{HCHO}$ mixing ratios derived from high-altitude mountain MAX-DOAS observations at midlatitudes and in the tropics, Atmos. Chem. Phys., 16, 28032817, https://doi.org/10.5194/acp-16-2803-2016, 2016.

Seinfeld, J. H. and Pandis, S. N.: Atmospheric Chemistry and Physics - From Air Pollution to Climate Change, 2nd edn., John Wiley \& Sons, Hoboken, New Jersey, 2006.

Singer, R. J., Crowley, J. N., Burrows, J. P., Schneider, W., and Moortgat, G. K.: Measurement of the Absorption CrossSection of Peroxynitric Acid between 210 and $330 \mathrm{~nm}$ in the Range 253-298 K, J. Photoch. Photobio. A, 48, 17-32, https://doi.org/10.1016/1010-6030(89)87086-8, 1989.

Staffelbach, T. A., Orlando, J. J., Tyndall, G. S., and Calvert, J. G.: The Uv-Visible Absorption-Spectrum and Photolysis Quantum Yields of Methylglyoxal, J. Geophys. Res.-Atmos., 100, 1418914198, https://doi.org/10.1029/95jd00541, 1995.

Stavrakou, T., Müller, J.-F., Boersma, K. F., van der A, R. J., Kurokawa, J., Ohara, T., and Zhang, Q.: Key chemical $\mathrm{NO}_{x}$ sink uncertainties and how they influence top-down emissions of nitrogen oxides, Atmos. Chem. Phys., 13, 9057-9082, https://doi.org/10.5194/acp-13-9057-2013, 2013.

Strand, A. and Hov, O.: The impact of man-made and natural $\mathrm{NO}_{x}$ emissions on upper tropospheric ozone: A twodimensional model study, Atmos. Environ., 30, 1291-1303, https://doi.org/10.1016/1352-2310(95)00413-0, 1996.

Sugimoto, N., Takezawa, S., and Takeuchi, N.: Time-Resolved, Dispersed Laser-Induced Fluorescence of $\mathrm{NO}_{2}$ - Observation of Collision-Induced Energy-Transfer Effect, Jpn. J. Appl. Phys., 1, 1536-1538, https://doi.org/10.1143/Jjap.21.1536, 1982.
Taketani, F., Kawai, M., Takahashi, K., and Matsumi, Y.: Trace detection of atmospheric $\mathrm{NO}_{2}$ by laser-induced fluorescence using a GaN diode laser and a diode-pumped YAG laser, Appl. Optics, 46, 907-915, https://doi.org/10.1364/Ao.46.000907, 2007.

Talukdar, R. K., Burkholder, J. B., Schmoltner, A. M., Roberts, J. M., Wilson, R. R., and Ravishankara, A. R.: Investigation of the Loss Processes for Peroxyacetyl Nitrate in the Atmosphere - UV Photolysis and Reaction with OH, J. Geophys. Res.-Atmos., 100, 14163-14173, https://doi.org/10.1029/95jd00545, 1995.

Thieser, J., Schuster, G., Schuladen, J., Phillips, G. J., Reiffs, A., Parchatka, U., Pöhler, D., Lelieveld, J., and Crowley, J. N.: A two-channel thermal dissociation cavity ring-down spectrometer for the detection of ambient $\mathrm{NO}_{2}, \mathrm{RO}_{2} \mathrm{NO}_{2}$ and $\mathrm{RONO}_{2}$, Atmos. Meas. Tech., 9, 553-576, https://doi.org/10.5194/amt-9553-2016, 2016.

Thornton, J. A., Wooldridge, P. J., and Cohen, R. C.: Atmospheric $\mathrm{NO}_{2}$ : In situ laser-induced fluorescence detection at parts per trillion mixing ratios, Anal. Chem., 72, 528-539, https://doi.org/10.1021/Ac9908905, 2000.

Vandaele, A. C., Hermans, C., Fally, S., Carleer, M., Colin, R., Merienne, M. F., Jenouvrier, A., and Coquart, B.: Highresolution Fourier transform measurement of the $\mathrm{NO}_{2}$ visible and near-infrared absorption cross sections: Temperature and pressure effects, J. Geophys. Res.-Atmos., 107, 4348, https://doi.org/10.1029/2001jd000971, 2002.

Villena, G., Bejan, I., Kurtenbach, R., Wiesen, P., and Kleffmann, J.: Interferences of commercial $\mathrm{NO}_{2}$ instruments in the urban atmosphere and in a smog chamber, Atmos. Meas. Tech., 5, 149-159, https://doi.org/10.5194/amt-5-149-2012, 2012.

Washenfelder, R. A., Langford, A. O., Fuchs, H., and Brown, S. S.: Measurement of glyoxal using an incoherent broadband cavity enhanced absorption spectrometer, Atmos. Chem. Phys., 8, 7779-7793, https://doi.org/10.5194/acp-8-7779-2008, 2008.

Wayne, R. P., Barnes, I., Biggs, P., Burrows, J. P., Canosamas, C. E., Hjorth, J., Lebras, G., Moortgat, G. K., Perner, D., Poulet, G., Restelli, G., and Sidebottom, H.: The Nitrate Radical - Physics, Chemistry, and the Atmosphere, Atmos. Environ. A, 25, 1-203, https://doi.org/10.1016/0960-1686(91)90192-A, 1991.

Wehry, E. L.: Modern fluorescence spectroscopy, Modern analytical chemistry, Plenum Press, New York, 1, 4 pp., 1976.

Weisstein, E. W.: CRC concise encyclopedia of mathematics, 2nd edn., Chapman \& Hall/CRC, Boca Raton, 3242 pp., 2003.

Wojtas, J., Stacewicz, T., Bielecki, Z., Czyzewski, A., and Nowakowski, M.: $\mathrm{NO}_{2}$ monitoring setup applying cavity enhanced absorption spectroscopy, Eurocon 2007, The International Conference on Computer as a Tool, 1-6, 2152-2154, https://doi.org/10.1109/EURCON.2007.4400586, 2007.

Wood, E. C., Wooldridge, P. J., Freese, J. H., Albrecht, T., and Cohen, R. C.: Prototype for In Situ Detection of Atmospheric $\mathrm{NO}_{3}$ and $\mathrm{N}_{2} \mathrm{O}_{5}$ via Laser-Induced Fluorescence, Environ. Sci. Technol., 37, 5732-5738, https://doi.org/10.1021/es034507w, 2003.

York, D., Evensen, N. M., Martinez, M. L., and Delgado, J. D.: Unified equations for the slope, intercept, and standard errors of the best straight line, Am. J. Phys., 72, 367-375, https://doi.org/10.1119/1.1632486, 2004. 